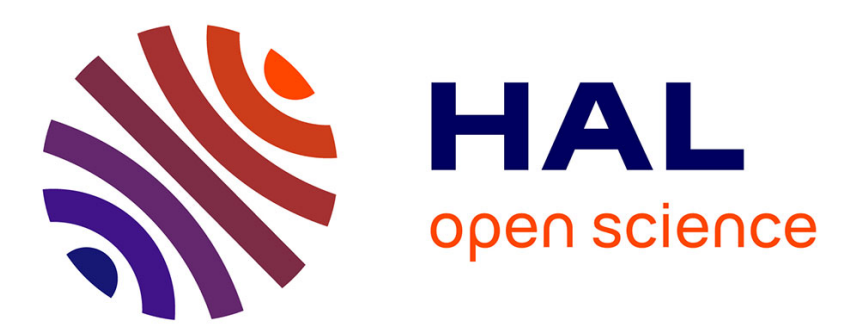

\title{
Market Discipline and the Use of Stock Market Data to Predict Bank Financial Distress
}

Isabelle Distinguin, Philippe Rous, Amine Tarazi

\section{To cite this version:}

Isabelle Distinguin, Philippe Rous, Amine Tarazi. Market Discipline and the Use of Stock Market Data to Predict Bank Financial Distress. Journal of Financial Services Research, 2006, 30 (2), pp.151-176. 10.1007/s10693-0016-6 . hal-00794214

\section{HAL Id: hal-00794214 \\ https://hal-unilim.archives-ouvertes.fr/hal-00794214}

Submitted on 13 Nov 2014

HAL is a multi-disciplinary open access archive for the deposit and dissemination of scientific research documents, whether they are published or not. The documents may come from teaching and research institutions in France or abroad, or from public or private research centers.
L'archive ouverte pluridisciplinaire HAL, est destinée au dépôt et à la diffusion de documents scientifiques de niveau recherche, publiés ou non, émanant des établissements d'enseignement et de recherche français ou étrangers, des laboratoires publics ou privés. 


\title{
Market Discipline and the Use of Stock Market Data to Predict Bank Financial Distress
}

\author{
Isabelle Distinguin, Philippe Rous, Amine Tarazi* \\ Université de Limoges, LAPE, 4 place du Présidial, 87000 Limoges, France
}

November 2005

\begin{abstract}
The aim of this paper is to assess the extent to which stock market information can be used to estimate leading indicators of bank financial distress. This issue is of importance because of the increased emphasis on market forces by the Basel II committee (pillar 3). We specify a Logit early warning model, designed for European banks, which is used to test if market based indicators add predictive value to models relying on accounting data. Tests are also conducted to study the robustness of the link between market information and financial downgrading in the light of the too-big-too-fail (safety net) and the bank opacity (asymmetric information) hypotheses. Whereas some of our results support the use of market related indicators (in line with those previously obtained in the literature), we show that the accuracy of the predictive power is dependent on the extent to which bank liabilities are market traded. For banks which heavily rely on (insured) deposits, the market seems unable to convey useful information and the amount of subordinated debt issued by banks does not contribute to any improvement in the expected link.
\end{abstract}

Key words: Bank, Market Discipline, Bank Risk, Market Prices

JEL Classification: G21, G28

\section{Introduction}

Until the early 90's early warning models of bank financial distress essentially relied on public information contained in financial statements (accounting data) and on macroeconomic variables. In recent years recommendations have aimed to enlarge the role of market forces to promote safe and sound banking systems as well as the use of market information by bank supervisors to improve the assessment of bank financial conditions (Berger, Davies and Flannery [2000], Flannery [1998, 2001]).

This increased emphasis on market forces is at the heart of the new regulatory framework developed by the Basel Committee on Banking and Supervision (Basel II Accord)

\footnotetext{
* Corresponding author. Tel. : +33-555-43-69-34; fax : +33-555-43-69-34

E-mail address: amine.tarazi@unilim.fr (A. Tarazi).
} 
which includes market discipline as one of its three pillars (BIS [2003]). By imposing greater disclosure the aim is to improve the quality of the information provided by banks to investors; market forces are therefore assumed to reinforce bank capital regulation and supervision to ensure safety. Under market discipline market prices and returns reflect the accurate level of individual bank risk because, unlike insured depositors, market investors will require a risk premium which may increase banks' cost of funding and therefore reduce risk taking incentives. Consequently, it has been suggested that market prices could be used by supervisors as signals and also complement accounting data in the design of early warning systems.

Under such an approach, as noted by Feldman and Levonian [2001], a major issue is whether the benefits from employing market information outweigh the costs and therefore ensure an efficient allocation of supervisory resources. Consequently, because the cost of using market information can be very high, a central question is whether market prices convey additional information which is not already included in accounting data (Curry, Elmer and Fissel [2002]).

Recent papers studying US banks have investigated the predictive power of models in which market variables are added to standard call report financial data (Curry, Elmer and Fissel [2002, 2003], Evanoff and Wall [2001]). Their findings support the idea that market variables improve the assessment of bank financial health. In the European context, Gropp, Vesala and Vulpes [2005] focused on selected market indicators and their use as leading indicators of bank financial distress. Their results show that indicators derived from market prices are able to predict changes in bank financial health at a relatively long time horizon. They also insist on the additional contribution of market indicators relatively to an average indicator based on accounting data.

The objective of this paper is two-fold: firstly, to construct an early warning system of bank financial distress specifically designed for European banks, and secondly to raise further issues, in the light of modern intermediation theory, ignored by the existing literature. More precisely, we start by building an early warning model based on downgrades by three rating agencies (Moody's, Standard and Poors and Fitch) and a large set of accounting and market indicators. We then raise the issue of the additional contribution of market indicators based on stock prices and specifically as regards the information conveyed by market prices for banking institutions which are inherently opaque firms (asymmetric information). We also question the opportunity of relying on market information in the light of the too-big-to-fail 
issue and the reliance on a safety net, that is the likelihood that a bank receives support from official or other sources (systemic risk).

The rest of the paper is laid out as follows. Section 2 discusses the issue and relates it to the existing literature. Section 3 presents our methodology to estimate an early warning model and to test our different propositions. Section 4 defines our sample and shows how our leading indicators were constructed. Section 5 presents our empirical findings and section 6 concludes.

\section{Issue and related literature}

The issue of the reliance on market prices either to assess bank individual risk, the accuracy of market discipline in banking, or to specifically predict bank financial distress has been widely addressed in the literature (see Flannery [1998, 2001]). In a strand of this literature the prices of different types of securities issued by banks (shares, bonds, subordinated bonds, certificates of deposits...) have been used to study the link between market variables and bank risk. Building on the findings of these papers another issue focused on the potential for market prices to serve as early signals of bank failures or financial distress.

Most of the existing literature focused on the prediction of large events such as actual bank closures or sharp downgrades by rating agencies or by official sources (supervisory ratings). Studying US banks, Curry, Elmer and Fissel [2003] showed that the prediction of a CAMEL (supervisory) rating downgrade to the lowest levels can be significantly improved by adding market variables to a set of accounting indicators. However, this predictive power was found to be significant only for banks in the greatest financial distress. Similarly, Gunther, Levonian and Moore [2001] showed that the inclusion of a market indicator such as the expected default frequency (EDF) improves the predictive power of a model based on accounting ratios and CAMEL ratings.

To our knowledge only one study was dedicated to the case of European banks (Gropp, Vesala and Vulpes [2005]). Based on a panel of 15 countries, their aim was to compare the properties of stock market and subordinated debt data as early indicators of Fitch/IBCA downgrades to $\mathrm{C}$ or below reflecting severe financial distress. They also showed that, beyond the information conveyed by a composite score variable based on accounting data, the equity market-based distance to default (KMV [2003]) significantly improves predictions up to an 18 months time horizon. 
This paper extends the earlier studies in several directions by proposing a framework which can be implemented for European banks and which enables to further raise two theoretical issues neglected in the existing literature.

Firstly, based on a broad panel of European banks our approach combines different frequency data (annual for accounting data and daily for market data) without imposing underlying restrictive assumptions implicit to some of the existing empirical models which are discussed in the next section.

Secondly, we focus on the predictive power of a large number of market indicators estimated solely from stock prices. Because European markets for other securities issued by banks (such as bonds or subordinated bonds) generally suffer from insufficient liquidity (inactive trading) our analysis is restricted to equityholders incentives and uses, in contrast to earlier studies, a greater variety of market indicators.

Thirdly, instead of focusing on bank failures or on severe financial distress we consider the prediction of any downward change in a bank's financial health. In this sense our view is that early detection of downgrades may play a major role in the implementation of prompt corrective action by regulators without jeopardizing strategic orientations followed by bank managers. In this sense we deal with the issue of identifying banks' future financial health deterioration by considering the information contained in the changes in indicators (financial ratios and/or market variables) rather than in their level as in previous studies.

Fourthly, our objective is also to test the robustness of results in the light of modern financial intermediation theory developed in the steps of Leland and Pyle [1977], Diamond and Dybvig [1983] and Diamond [1984]. Banks and financial intermediaries are considered as agents that play a major role in the financial system as information intermediaries. They collect and process information namely about loan customers (Diamond 1984, 1991) which implies that they possess private information. As such, market participants (outsiders) should have limited ability to monitor banks and market discipline in the banking industry should not play a prominent role. Therefore, due to the inherent opacity of banks (opacity effect) and the need to support large banking institutions (too-big-to-fail effect) we question the ability of market indicators to accurately predict future financial distress for different types of banks and financial institutions. 


\section{Methodology}

As a first step, we implement a procedure to test for the specific and additional contribution of various market indicators to the prediction of bank financial distress. We then study the stability of the predictive power of early warning market indicators with respect to bank size and balance sheet structure.

\subsection{Identifying the additional contribution of market indicators}

Assessing the ability of market indicators to predict bank financial distress requires the choice of an event capturing the changing status of each bank. In the absence of actual bankruptcies in the European banking industry in sufficient number, we identify changes in a bank's financial condition through downgrading announcements by three rating agencies (Fitch, Standard \& Poors, and Moody's). Most studies on US banks considered either explicit bank failures or supervisory ratings (Curry, Elmer and Fissel [2003], Gunther, Levonian and Moore [2004]). Because of the lack of access to explicit supervisory ratings in Europe which are confidential in most countries, we rely on public information disclosed by private agencies. In this sense the selection of our events is close to the method developed by Gropp, Vesala and Vulpes [2005] who use downgrades of Fitch individual ratings to C or below as a proxy of bank failure. In contrast to their study, and because we are more concerned by the actual information content of stock prices than their ability to forecast failures, we consider that any downgrading announcement should be retained in our study. This implies that a deterioration in a bank's financial health is captured in our study by a downgrading from any initial level and down to any level below. Identifying both narrow and broad changes is essential for the robustness of results and provides a more general framework for early warning models estimation. Also, accounting for downgrades by more than just one rating agency ensures that, in our specification, the event date is the earliest possible with respect to announcements by one of the three major agencies covering financial institutions in Europe.

We then define two sets of variables : accounting indicators and equity market based indicators likely to predict a future downgrade in a bank's financial condition. When assessing the link between the dependent variable and early warning indicators several shortcomings need to be tackled. Firstly, the different variables are not available at the same frequencies (daily for market indicators, yearly for accounting indicators). Whereas some studies proceed by linear or more advanced interpolation of low frequency data (i.e. Gropp and alii [2005]) we consider that such a procedure is not convenient because it implies that in some cases future information may be used to explain current downgrades. Therefore instead 
of departing from each event (downgrade by a rating agency) to then compute all the relevant accounting and market indicators on a backward given time horizon we deal with the issue of predictability departing from each date at which accounting data information is available. In the case of European banks this date is 31 December of each year. We then consider events taking place in the four subsequent quarters following this date.

Formally, consider that for each of the $\mathrm{N}$ banks of the sample, there are $\mathrm{T}$ observations through time for accounting indicators. These dates are retained as the starting point for the prediction implementation. To ensure that our empirical implementation relies on clean and robust events we then impose that, for a bank (b), a starting point $(\mathrm{t})$ and a $(\mathrm{K})$ horizon forecast ( $\mathrm{K}=1,2,3$ and 4 quarters ahead), the value taken by the dependant binary variable $\mathrm{Y}$ is equal to :

.1 if downgrading occurs for this bank (b) within $[\mathrm{t}, \mathrm{t}+\mathrm{K}]$ with no upgrading taking place during the whole calendar year to avoid noise around the event date. When several downgrades are announced by a given rating agency or by any of the three rating agencies only the first date is taken into account. In addition, because our setting is based on calendar years and quarters we need to check that a downgrade occurring in the last quarter of a given year is not followed by a downgrade by another rating agency in the first quarter of the following year (for example, a downgrade in December followed by a downgrade in January which is actually the same event). In such cases, again, only the first date is taken into account).

.0 if the rating remains unaltered throughout the end of the calendar year;

. in any other case, $\mathrm{Y}$ is considered as "non available" NA ${ }^{1}$.

The following figure illustrates the definition of the dependant variable $(0,1, \mathrm{NA})$ for a 3 quarters horizon forecast :
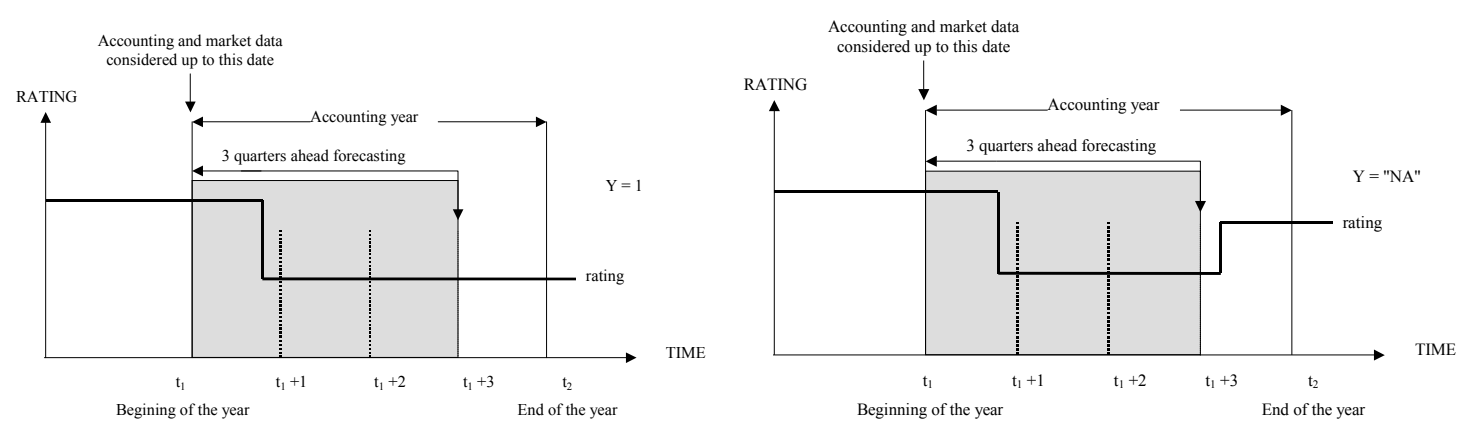

\footnotetext{
${ }^{1}$ Alternatively, our setting could also account for upgrades. Because our aim is to focus on financial deterioration by using rating changes as proxies, we ignored upgrades. Consequently, in our setting, the prediction of downgrades $(\mathrm{Y}=1)$ is more stringent because the significance of explanatoy variables is a priori more difficult to establish.
} 

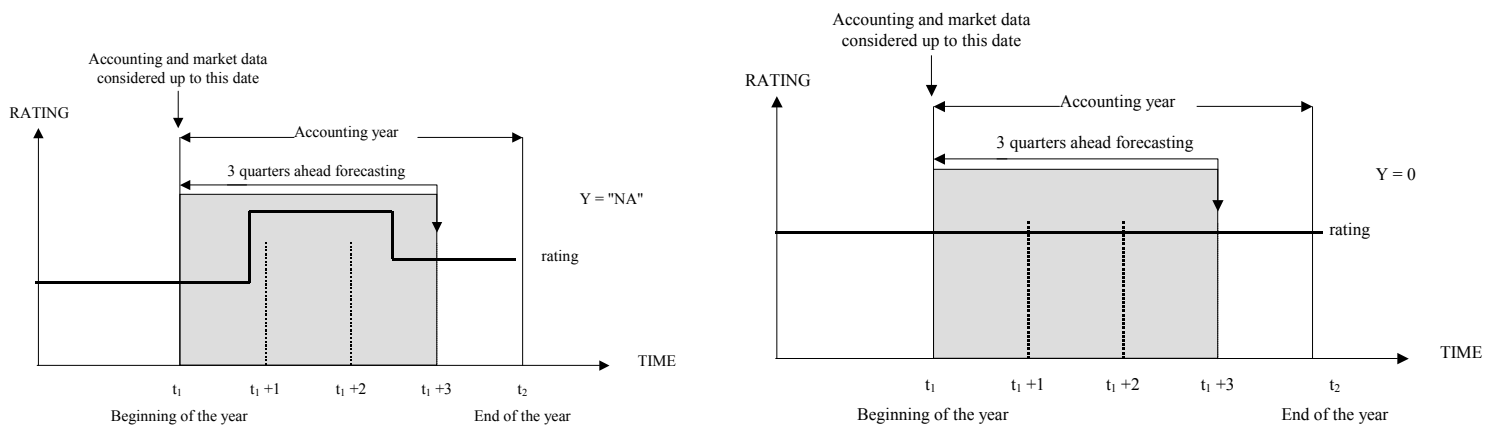

By defining the dependant variable as such we prevent the same values taken by accounting or market indicators from being related with different rating changes occurred for a given bank. For a given prediction horizon (1, 2, 3 or 4 quarters), there are, theoretically, $\mathrm{N}$ $\times \mathrm{T}$ observations $\mathrm{Y}_{\mathrm{i}}$ for the explained binary variable where i refers to a bank (b), a starting prediction point $(\mathrm{t})$ and a forecasting horizon $(\mathrm{K})$ :

$$
\mathrm{i}=\mathrm{i}(\mathrm{b}, \mathrm{t}, \mathrm{K})
$$

Accounting $\mathrm{C}_{\mathrm{ji}(\mathrm{b}, \mathrm{t}, \mathrm{K})}$ and market $\mathrm{M}_{\mathrm{li}(\mathrm{b}, \mathrm{t}, \mathrm{K})}$ indicators are computed at a starting point $(t)$, that is on December $31^{\text {th }}$ of each year. Consequently, the interpolation of the missing accounting data as implemented by Gropp, Vesala and Vulpes [2005] to estimate their distance to default indicator is suitably avoided ensuring that the information content of accounting data based indicators is not inappropriately upward biased (prediction at time $\mathrm{t}_{0}$ based on data obtained by interpolation of past but also future data regarding financial condition at time $t_{1}>t_{0}$ ). Formally, this means that the estimation of early indicators incorporating accounting data or both accounting and market data (such as the distance to default) is not performed using information on the state of the world subsequent to the prediction date.

To assess the relationship between market and accounting early warning indicators and rating downgrades we use a logit model at four time period horizons to estimate the probability of a downgrade :

$$
\operatorname{Prob}\left\{\mathrm{Y}_{\mathrm{i}}=1\right\}=\Phi\left(\alpha+\sum_{j=1}^{J} \beta_{j} C_{j i}+\sum_{l=1}^{L} \gamma_{l} M_{l i}\right)
$$

where $\mathrm{C}_{\mathrm{ji}}$ and $\mathrm{M}_{\mathrm{li}}$ stand for the $\mathrm{j}^{\text {th }}$ accounting indicator and the $1^{\text {th }}$ market indicator respectively and $\Phi($.$) denotes the cumulated logistic distribution function. Maximum$ likelihood estimators of the coefficients $\left(\alpha, \beta_{\mathrm{j}}, \gamma_{1}\right)$ are used and robust Huber-White 
covariance matrix estimation allows for possible misspecification of the error term distribution.

For each prediction horizon (models 1 to 4 ), the most powerful predictors of financial deterioration are selected in the following manner. As a first step, we investigate the predictive power of the sole accounting indicators regardless of market information. The most performing indicators are selected via a stepwise process ${ }^{2}$.

Such a procedure identifies the sub-set of accounting indicators that optimally predict financial weakening. As a second step, we assess the marginal contribution of market indicators by extending the filtering process (stepwise) to a large set of market indicators by adding the latter to the optimal sub-set of accounting indicators obtained in the first step ${ }^{3}$.

\subsection{Predicting downgrades : too-big-to-fail and opacity effects}

We then test for the stability of the above relationship by allowing for possible size effects or bank opacity effects. We control for such effects by conducting several tests. Firstly, dummy variables are constructed capturing too-big-to-fail banks or banks likely to benefit from either a public or private support (safety net). Such variables are also defined on the basis of a set of standard financial ratios which are generally used as opacity proxies in the literature. Dummies are then introduced in the different models (models 1 to 4 ) to conduct a series of stability tests. Secondly, tests are also carried out by estimating the different models on restricted samples of banks.

\footnotetext{
${ }^{2}$ As a common rule of thumb, we retained a $5 \%$ level for type 1 error ; a Max (Min) LR statistic was used as a criterion for adding (ruling out) each potential indicator to (from) the selected set.

${ }^{3}$ As noted by an anonymous referee, because financial market data arrive more frequently than accounting data (higher frequency) a possible extension of our work is to include, for each horizon, market indicators computed on the basis of current information (for example, for the one year horizon, consider price changes up to the fourth quarter). However, our aim here is mainly to study the length of the predictive time horizon $(1,2,3$ or 4 quarters) allowing supervisors to implement prompt corrective action well ahead (prior to failure) and to test if the accuracy of the predictive power depends on bank opacity and the liability structure of banks. Naturally, we should expect that stock market based indicators perform better (higher marginal contribution) when we move closer towards the event date (downgrade).
} 


\section{Sample and indicators}

\subsection{Sample}

Table 1 : distribution of banks by country and specialisation

\begin{tabular}{|c|c|}
\hline Country & Numbers \\
\hline Germany & 7 \\
\hline Denmark & 1 \\
\hline Spain & 5 \\
\hline France & 8 \\
\hline Greece & 2 \\
\hline Ireland & 1 \\
\hline Italy & 15 \\
\hline Luxemburg & 1 \\
\hline Norway & 2 \\
\hline The Netherlands & 4 \\
\hline Portugal & 4 \\
\hline United Kingdom & 11 \\
\hline Sweden & 1 \\
\hline Switzerland & 2 \\
\hline
\end{tabular}

\begin{tabular}{|c|c|}
\hline Specialisation & Numbers \\
\hline commercial bank & 31 \\
\hline cooperative bank & 7 \\
\hline medium and long term credit bank & 2 \\
\hline real estate and mortgage bank & 6 \\
\hline savings bank & 2 \\
\hline investment bank & 3 \\
\hline bank holding and holding coimpany & 9 \\
\hline non banking credit institution & 4 \\
\hline
\end{tabular}

The sample consists of events (downgrades or absence of downgrades) related to 64 European banks regularly listed on the stock market and for which ratings from at least one of the three major rating agencies (Fitch, Moody's or Standard and Poors) are available during the 1995-2002 period. Table 1 presents the distribution of these banks by country and specialisation.

Daily market data (bank stock prices) are taken from Datastream International and annual income statements and balance sheets come from Bankscope Fitch IBCA. Our sample of banks is restricted to EU banks for which market data is reliable for the purpose of our study. Only actively and regularly traded stocks were considered. Table 2 shows descriptive statistics on our sample of banks which exhibits a relatively high level of heterogeneity. This enables us to investigate further on the robustness of the relationship between early indicators and the probability of financial deterioration with respect to differences in size or balance sheet structure. 
Table 2 : The sample of banks : summary accounting statistics from $31 / 12 / 1995$ to $31 / 12 / 2001$

\begin{tabular}{|c|c|c|c|c|}
\hline & Mean & $\begin{array}{c}\text { Standard } \\
\text { deviation }\end{array}$ & Minimum & Maximum \\
\hline TOTAL ASSETS in million of euros & 118343.42 & 191634.00 & 1407.13 & 922793.50 \\
\hline NET LOANS/ TOTAL ASSETS & 53.75 & 18.75 & 4.60 & 86.85 \\
\hline DEPOSITS/ TOTAL ASSETS & 62.23 & 21.14 & 0.00 & 92.67 \\
\hline SUBORDINATED DEBT/ TOTAL ASSETS & 1.50 & 0.88 & 0.00 & 3.59 \\
\hline DEPOSITS in million of euros & 72338.04 & 107114.57 & 437.81 & 412237.10 \\
\hline SUBORDINATED DEBT in million of euros & 2031.45 & 3091.04 & 0 & 10309.50 \\
\hline TIER 1 RATIO & 7.95 & 2.02 & 4.44 & 13.27 \\
\hline ROA & 0.82 & 0.67 & -0.08 & 3.72 \\
\hline
\end{tabular}

Ratios are in percentage. Net loans are gross loans - loan loss reserves. Each mean is calculated as $\overline{\mathrm{X}}=\frac{1}{\mathrm{NT}} \sum_{\mathrm{t}=1}^{\mathrm{T}} \sum_{\mathrm{j}=1}^{\mathrm{N}} \mathrm{X}_{\mathrm{jt}}$ with $N$ the number of banks and $T$ the number of financial reports. The standard deviations are calculated on a similar basis.

\subsection{Financial deterioration indicator}

Table 3 provides information about Fitch, Moody's and Standard and Poors' ratings. These ratings are employed to build the binary dependent variable previously defined. Because the method used to construct the dependent variable implies several restrictions (discussed in the previous section) only a limited number of downgrades are taken into account. As a whole, because only the first date is used to construct the binary variable Y when a bank is subsequently downgraded by different rating agencies, our final (clean) set is limited to 62 downgrades ( 28 by Standard and Poors, 22 by Fitch and 12 by Moody's) distributed as follows : 15 for the first quarters, 14 for the second quarters, 9 for the third quarters and 24 for the fourth quarters. While the proportion of S\&P downgrades is initially relatively high, because we considered all types of downgrades by each rating agency, our final clean sample is reasonably balanced.

Table 3 : Distribution of downgrades

\begin{tabular}{|c|c|c|c|c|c|c|c|}
\hline & $\mathbf{1 9 9 6}$ & $\mathbf{1 9 9 7}$ & $\mathbf{1 9 9 8}$ & $\mathbf{1 9 9 9}$ & $\mathbf{2 0 0 0}$ & $\mathbf{2 0 0 1}$ & $\mathbf{2 0 0 2}$ \\
\hline $\begin{array}{c}252(62) \\
\text { downgrades }\end{array}$ & $5(3)$ & $12(4)$ & $14(7)$ & $21(5)$ & $27(5)$ & $61(12)$ & $112(24)$ \\
\hline $\begin{array}{c}117(26) \\
\text { downgrades by } \\
\text { Standard and Poors }\end{array}$ & $1(1)$ & $2(1)$ & $3(2)$ & $11(5)$ & $11(1)$ & $28(6)$ & $61(10)$ \\
\hline $\begin{array}{c}67(22) \text { downgrades } \\
\text { by Fitch }\end{array}$ & $4(2)$ & $1(1)$ & $7(3)$ & $5(2)$ & $10(2)$ & $17(4)$ & $23(8)$ \\
\hline $\begin{array}{c}68(14) \\
\text { downgrades by } \\
\text { Moody's }\end{array}$ & $0(0)$ & $9(2)$ & $4(2)$ & $5(0)$ & $6(2)$ & $16(2)$ & $28(6)$ \\
\hline
\end{tabular}

Numbers of clean downgrades are shown in parentheses. Sources : Bankscope Fitch IBCA 


\subsection{Accounting indicators}

As mentioned previously, we define several accounting indicators $\mathrm{C}_{\mathrm{i}(\mathrm{b}, \mathrm{t})}$ that are likely to predict bank financial deterioration. Table 4 defines the set of ratios $\mathrm{R}_{\mathrm{i}(\mathrm{b}, \mathrm{t})}$ which we employ and which are commonly used in the literature to assess banks' financial condition. These ratios $\mathrm{R}_{\mathrm{i}}$ can be distributed into four categories corresponding to the CAEL rating : Capital, Asset quality, Earnings and Liquidity. Several ratios are defined for each category.

Accounting ratios can be introduced in such prediction models either in level or in variation (first order difference). Most of the previous studies considered these ratios in level (Gunther, Levonian and Moore [2001], Curry, Elmer and Fissel [2002]) which can be justified when it comes to predict an event like a failure. However, if the aim is rather to predict a change in financial health it seems more appropriate to introduce not the values taken by the ratios, but their time changes. Besides, in this study, all banks are treated equally regardless of their initial financial strength. This means that the downgrade of a sound and safe bank (as might be reflected by the level of financial ratios) can only be captured by changes in the values of ratios. Also, because our sample consists of banks with a broad range of ratings, considering the values taken by financial indicators would be inappropriate. Therefore we define $C_{j i(b, t)}$, the change in the value of the accounting ratio $R_{j i}$ as : $C_{j i(b, t)}=\Delta R_{j i(b, t)}=R_{j i(b, t)}$ -

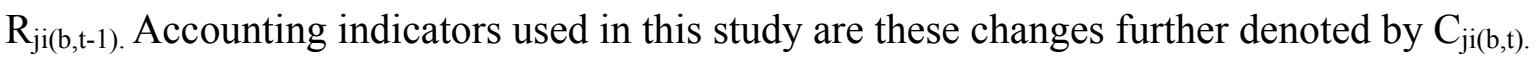


$\underline{\text { Table } 4}$ : Accounting ratios $\mathrm{R}_{\mathrm{j}}$

\begin{tabular}{|c|c|c|}
\hline Category & Name & Definitions \\
\hline Capital & $\begin{array}{l}\text { TIER } \\
\text { CAPITAL } \\
\text { KPA } \\
\text { KPCN } \\
\text { KPD } \\
\text { KPL } \\
\text { FPA } \\
\text { FPCN } \\
\text { FPD } \\
\text { FPL }\end{array}$ & $\begin{array}{l}\text { Tier } 1 \text { capital/ risk weighted assets and off balance sheet risks } \\
\text { (Tier1 + Tier } 2 \text { capital)/ risk weighted assets and off balance sheet risks } \\
\text { Equity/ Total assets } \\
\text { Equity / (gross loans - loan loss reserves) } \\
\text { Equity / Customer and short term funding } \\
\text { Equity / Liabilities } \\
\text { Capital funds/ Total assets }{ }^{4} \\
\text { Capital funds / (gross loans - loan loss reserves) } \\
\text { Capital funds / Customer and short term funding } \\
\text { Capital funds / Liabilities }\end{array}$ \\
\hline Asset quality & $\begin{array}{c}\text { PROVCB } \\
\text { DOTREV } \\
\text { PROVA } \\
\text { DOTA } \\
\text { DOTCB } \\
\text { INDIC }\end{array}$ & $\begin{array}{l}\text { Loan loss reserves/ Gross loans } \\
\text { Loan loss provisions/ Net interest revenue } \\
\text { Loan loss reserves / Total assets } \\
\text { Loan loss provisions / Total assets } \\
\text { Loan loss provisions / Gross loans } \\
\text { Risk weighted assets and off balance sheet risks (inferred from the Cooke } \\
\text { ratio)/ Total assets }\end{array}$ \\
\hline Earnings & $\begin{array}{l}\text { INTAP } \\
\text { INTAM } \\
\text { ROA } \\
\text { ROE }\end{array}$ & $\begin{array}{l}\text { Net interest revenue/Average earning assets } \\
\text { Net interest revenue/ Total assets } \\
\text { Return on assets = Net Income/Total assets } \\
\text { Return on equity = Net Income/Equity }\end{array}$ \\
\hline Liquidity & $\begin{array}{l}\text { INTERB } \\
\text { CBDEPST } \\
\text { ALD } \\
\text { ALREF }\end{array}$ & $\begin{array}{l}\text { Interbank assets/ Interbank liabilities } \\
\text { Gross loans/ Customer and short term funding } \\
\text { Liquid assets/ Customer and short term funding } \\
\text { Liquid assets / Total deposits and borrowings }\end{array}$ \\
\hline
\end{tabular}

\footnotetext{
${ }^{4}$ Capital funds are defined as : Equity + Hybrid Capital + Subordinated Debt.

${ }^{5}$ See Goyeau, Sauviat, Tarazi (1998).
} 
Table 5 : Market indicators

\begin{tabular}{|c|c|c|}
\hline Indicators & Definition & $\begin{array}{l}\text { Expected sign of the } \\
\text { coefficient }\end{array}$ \\
\hline LNP & Difference between the natural logarithm of market price and its moving average calculated on 261 days. & Negative \\
\hline RCUM & $\begin{array}{l}\text { Cumulative return : } \\
R C U M_{b t}=\left(\left(\prod_{k=1}^{65}\left(1+r_{b, t-k+1}\right)\right)-1\right) \text { with } \mathrm{r}_{\mathrm{b}, t+1}=\left(P_{b, t+1}-P_{b, t}\right) / P_{b, t} \text { where } \mathrm{r}_{\mathrm{bt}} \text { is the daily return of the stock } \mathrm{b} \text {; this cumulative return is } \\
\text { calculated on the fourth quarter of the accounting period (financial year) preceding the event, } \mathrm{P}_{\mathrm{bt}} \text { is the daily stock price of bank } \mathrm{b} \text {. }\end{array}$ & Negative \\
\hline RCUM_NEG & $\begin{array}{l}\text { Dummy variable equal to } 1 \text { if the cumulative return is negative in the two last quarters of the accounting period (financial year) } \\
\text { preceding the event and } 0 \text { otherwise. }\end{array}$ & Positive \\
\hline EXCRCUM & $\begin{array}{l}\text { Cumulative market excess return : } \\
\qquad \operatorname{EXCRCUM}_{b, t}=\left(\left(\prod_{k=1}^{65}\left(1+r_{b, t-k+1}\right)\right)-1\right)-\left(\left(\prod_{k=1}^{65}\left(1+r_{m, t-k+1}\right)\right)-1\right) \\
\text { with } \mathrm{r}_{\mathrm{m}} \text { the daily market return calculated from the country specific market index extracted from Datastream International for the fourth } \\
\text { quarter of the financial exercise preceding the event. }\end{array}$ & Negative \\
\hline EXCRCUM_NEG & $\begin{array}{l}\text { Dummy variable equal to } 1 \text { if the cumulative market excess return is negative in the two last quarters of the accounting period (financial } \\
\text { year) preceding the event and } 0 \text { otherwise. }\end{array}$ & Positive \\
\hline $\mathrm{RAC}$ & $\begin{array}{l}\text { Cumulative abnormal returns on the fourth quarter of the accounting period (financial year) preceding the event: } \\
\mathrm{RAC}_{\mathrm{bt}}=\sum_{k=1}^{65} R A_{b, t-k+1} \text { with } \mathrm{RA}_{\mathrm{bt}}=\mathrm{R}_{\mathrm{bt}}-\left(\hat{\alpha}+\hat{\beta} R_{m t}\right) \text {, the market model is estimated on the third quarter of the accounting period (financial } \\
\text { year) preceding the event }\end{array}$ & Negative \\
\hline$\triangle \mathrm{ECTYP}$ & $\begin{array}{l}\text { Change in the standard deviation of daily returns between the third and fourth quarter of the accounting period (financial year) } \\
\text { preceding the event }\end{array}$ & Positive \\
\hline$\triangle \mathrm{BETA}$ & $\begin{array}{l}\text { Change in the market model beta }\left(\hat{R}_{b t}=\hat{\alpha}+\hat{\beta} R_{m t}\right) \text { between the third and fourth quarter of the accounting period (financial year) } \\
\text { preceding the event }\end{array}$ & Positive \\
\hline$\triangle \mathrm{RISKSPEC}$ & $\begin{array}{l}\text { Change in specific risk : standard deviation of the market model residual between the third and fourth quarter of the accounting period } \\
\text { (financial year) preceding the event. }\end{array}$ & Positive \\
\hline$\Delta \mathrm{Z}$ & $\begin{array}{l}\text { Change in the } \mathrm{Z} \text {-score between the third and fourth quarter of the accounting period (financial year) preceding the event with : } \\
\mathrm{Z}=\left(1+\bar{r}_{b}\right) / \sigma_{r} \text { where } \bar{r}_{b} \text { is the mean return of stock } \mathrm{b} \text { on the preceding quarter and } \sigma_{r} \text { the standard deviation of the return. }\end{array}$ & Negative \\
\hline$\Delta \mathrm{DD}$ & $\begin{array}{l}\text { Annual change in the distance to default estimated at the end of the accounting period (financial year) preceding the event. The distance } \\
\text { to default is inferred from the market value of a risky debt (Merton (1977)) based on the Black and Scholes (1973) option pricing } \\
\text { formula. Details on the estimation method and on the data are presented in appendix. }\end{array}$ & Negative \\
\hline
\end{tabular}




\subsection{Market indicators}

We can reasonably assume that the equity market conveys useful information to predict financial deterioration. If the market is efficient, prices and returns should incorporate the risk exposure of banks and thus their default risk. Table 5 presents the market based indicators used in this study which are constructed from daily equity prices. In contrast with previous literature we cover a broad range of indicators to compare their relative predictive power. The variables LNP, RCUM, EXCRCUM, RCUM_NEG, EXCRCUM_NEG, RAC are used to capture the effects of shocks or the presence of abnormal returns. The variables $\triangle \mathrm{ECTYP}, \triangle \mathrm{BETA}$ and $\triangle \mathrm{RISKSPEC}$ are employed to detect risk changes and $\triangle \mathrm{Z}$ and $\triangle \mathrm{DD}$ changes in the probability of failure. Some of the variables used in this study have already been introduced in similar models of bank distress to test the additional predictive contribution of stock market prices. Market excess return (EXCRCUM) and durably negative market excess return (EXCRCUM_NEG) were introduced by Elmer and Fissel [2001]. Gropp, Vesala and Vulpes [2005] used the value taken by the distance to default variable. In this study, several market indicators are introduced in difference in the predictive equation (variables reflecting market assessment of risk or the probability of failure).

\section{Empirical results}

As a preliminary stage we consider the predictive power of each indicator by running logistic regressions in which each explanatory variable is introduced separately. We then present the best performing accounting based models for the different prediction horizons. The additional contribution of market indicators is then assessed by augmenting each model with market indicators which are selected by the stepwise procedure. Eventually, tests are conducted to study the robustness of the predictive power of market indicators with respect to bank size (too-big-to-fail effect) and bank balance sheet structure (opacity effect).

\subsection{Individual contribution of indicators}

Table 6 shows the results obtained for each horizon (models 1 to 4), when each early indicator is separately introduced in the model. Results are only reported when coefficients are at least significant at the $10 \%$ level. The last column of table 6 (model 5) shows the results that are obtained when the dependent binary variable $\mathrm{Y}$ is based on sharp downgrades reflecting severe financial distress (failure or quasi-failure). 
$\underline{\text { Table } 6}$ : Financial deterioration and early indicators : simple regressions Model specification : $\operatorname{Prob}\left\{\mathrm{Y}_{\mathrm{i}}=1\right\}=\Phi\left(\alpha+\beta \mathrm{X}_{\mathrm{i}}\right)$

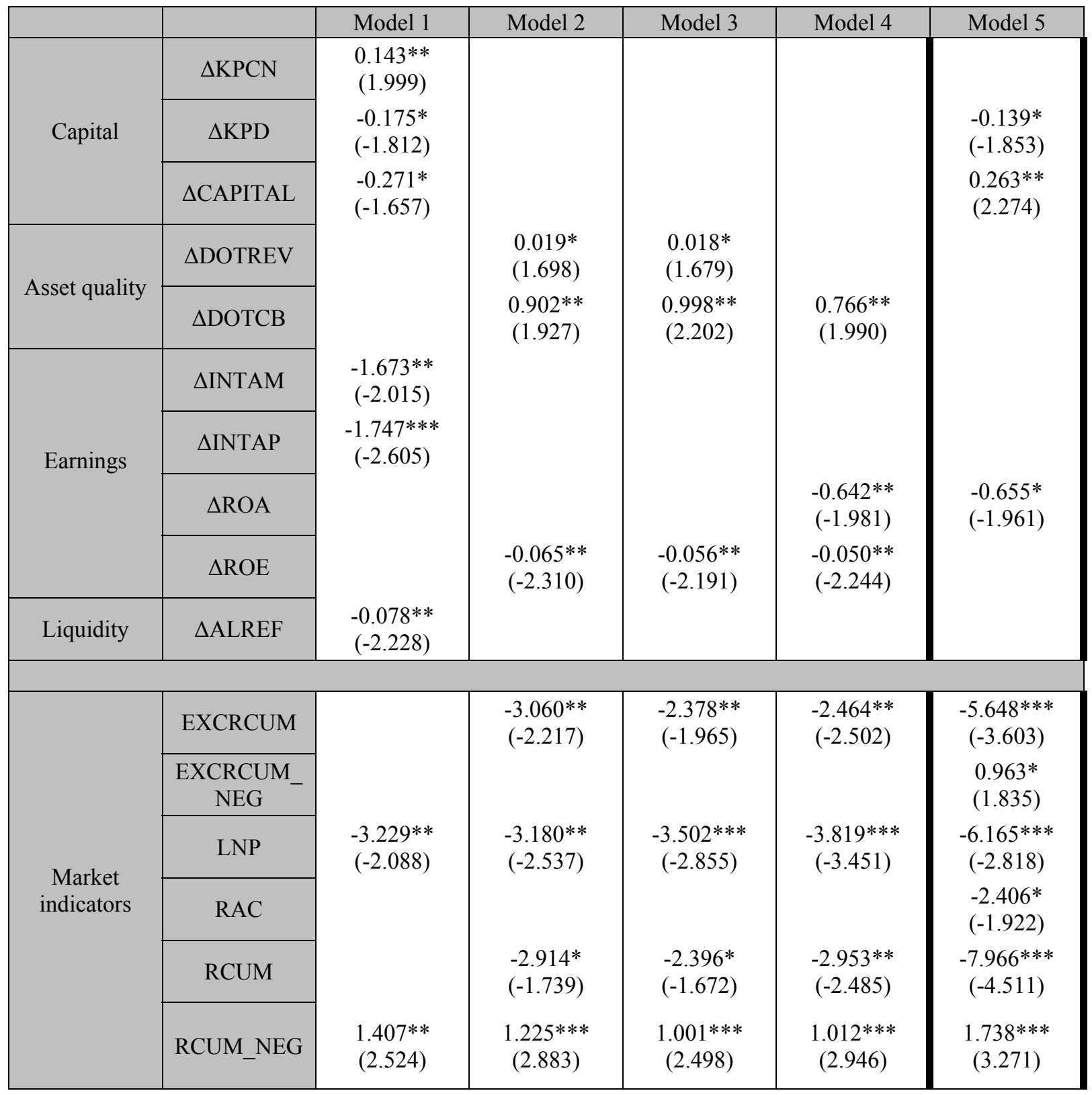

This table reports simple logit estimation results : for each model, the dependent variable is separately regressed on each explanatory variable and a constant. Models 1, 2, 3 and 4 explain downgradings (whatever their extent) occurring respectively in less than 1, 2, 3 and 4 quarters. Model 5 explains only downgradings occurring in less than 4 quarters and reflecting quasi-insolvency. Standard errors are adjusted using the HuberWhite method. *,** and *** indicate significance respectively at $10 \%, 5 \%$ and $1 \%$ levels. Z-statistics are shown in parenthesis.

On the whole, the coefficients associated to changes in profitability ratios ( $\triangle \mathrm{ROA}$ and $\triangle \mathrm{ROE})$ or to loan loss provisions $(\triangle \mathrm{DOTCB})$ are significant only for the longer horizons $(2,3$ and 4 quarters). Inversely changes in capital ratios ( $\triangle \mathrm{KPCN}, \triangle \mathrm{KPD}$ and $\triangle \mathrm{CAPITAL}$ ) perform 
significantly only for the shortest horizon (1 quarter). These results suggest that income statement information (flows) allows earlier prediction of financial downgrades whereas balance sheet information (stocks) which is by definition less flexible might only be useful for relatively shorter horizons. The negative (expected sign) and significant contribution of the change in the liquidity ratio ( $\triangle \mathrm{ALREF}$ ) for the shortest horizon solely suggests that downgrades are shortly preceded by a partial liquidation of liquid assets. However, similarly to balance sheet information this signal can only be employed at a short horizon. On the whole, these preliminary results favour indicators which combine information contained in both balance sheets and income statements for longer horizons predictions.

The results obtained in table 6 for market indicators show that for every time horizon a number of market based variables significantly predict financial deterioration (downgrades). In each logistic regression (for every prediction horizon) the coefficients of the variables capturing downward or upward trends in stock prices or negative cumulative returns (LNP and RCUM_NEG) are highly significant with the expected sign. Cumulative returns (RCUM) and cumulative excess returns (EXCRCUM) are significant for three out of four horizons. These preliminary results suggest that market based indicators may well contribute to predict financial difficulties at a relatively long time horizon.

To check for the robustness of these different results, with regards to our sample, regressions (see Table A1 in appendix) were also ran by retaining for each quarter only the downgrades which occurred within the considered quarter. This experiment, which restricts the number of observations, lead to similar results. The results obtained in models 1 to 4 are also compared to those that are obtained when early indicators are used to predict severe financial difficulties (model 5 in table 6). In model 5 the dependant variable is constructed using downgrades in the Fitch Individual rating to $\mathrm{C}$ or below as in Gropp, Vesala and Vulpes $[2005]^{6}$ as well as downgrades in Moody's financial strength ratings to similar levels (our sample contains 17 "clean" ( $\mathrm{Y}=1)$ downgrades of this type). These ratings aim to assess the financial strength of an institution by explicitly removing the safety net, that is the likelihood of being supported by a parent bank or by public authorities. The obtained results clearly show that among our relatively large set of accounting and market indicators, variables which could be retained to predict downgrades of any level (weak or strong deterioration in

\footnotetext{
${ }^{6}$ According to Gropp, Vesala and Vulpes [2005] a downgrade in Fitch Individual rating to C or below is generally followed within one year's time by a government or parent bank intervention.
} 
financial strength) are also significant to predict sharp downgrades (failure or quasi-failure). Namely, there is no significant market based variable present in model 5 (prediction of failures) which is absent from equations 1 to 4 (prediction of either severe or moderate financial deterioration).

\subsection{Contribution of accounting indicators}

Table 7 : Financial deterioration and accounting indicators

$$
\text { Model specification }: \operatorname{Prob}\left\{\mathrm{Y}_{\mathrm{i}}=1\right\}=\Phi\left(\alpha+\sum_{\mathrm{j}=1}^{\mathrm{J}} \beta_{\mathrm{j}} \mathrm{C}_{\mathrm{ji}}\right)
$$

\begin{tabular}{|c|c|c|c|c|c|}
\hline & & Model 1 & Model 2 & Model 3 & Model 4 \\
\hline Constant & & $\begin{array}{c}-2.723 * * * \\
(-8.297)\end{array}$ & $\begin{array}{c}-1.919 * * * \\
(-8.630)\end{array}$ & $\begin{array}{c}-1.612 * * * \\
(-8.364)\end{array}$ & $\begin{array}{c}-1.099 * * * \\
(-7.059)\end{array}$ \\
\hline \multirow{2}{*}{ Earnings ratios } & $\triangle \mathrm{INTAP}$ & \multirow[t]{2}{*}{$\begin{array}{r}-1.717 * * \\
(-2.537)\end{array}$} & & & \\
\hline & $\triangle \mathrm{ROE}$ & & $\begin{array}{c}-0.084 * * * \\
(-2.990)\end{array}$ & $\begin{array}{c}-0.072 * * * \\
(-2.743)\end{array}$ & $\begin{array}{c}-0.061 * * * \\
(-2.731)\end{array}$ \\
\hline $\begin{array}{c}\text { Mc Fadden } \mathrm{R}^{2} \\
\text { Total number of observations }\end{array}$ & & $\begin{array}{c}0.049 \\
187\end{array}$ & $\begin{array}{c}0.045 \\
204\end{array}$ & $\begin{array}{c}0.032 \\
213\end{array}$ & $\begin{array}{c}0.024 \\
237\end{array}$ \\
\hline $\begin{array}{l}\text { Number of observations with } \\
\qquad Y=1\end{array}$ & & 15 & 29 & 38 & 62 \\
\hline
\end{tabular}

This table reports logit estimation results obtained with the dependent variable regressed on a constant and the accounting indicators selected by the stepwise process. Models 1, 2, 3 and 4 explain downgradings occurring respectively in less than 1, 2, 3 and 4 quarters. Standard errors are adjusted using the Huber-White method. *, $* *$ and $* * *$ indicate significance respectively at 10\%, 5\% and $1 \%$ levels. Z-statistics are shown in parenthesis. The number of observations differs in the different models because all data are not available for each bank, each year and each indicator.

In line with the method discussed in section 3, we identify for each predictive horizon the most powerful subset of accounting indicators (stepwise procedure) in explaining the probability of a future downgrade. The results (table 7) show that for every horizon accounting data information is conveyed by one or two indicators. To deal with collinearity we also conducted the stepwise procedure by considering in the set of accounting indicators variables which were not correlated. Both procedures lead to the same optimal subset of variables for every time horizon. Not surprisingly, we obtain results which are in line with those previously obtained. Indicators which better contribute to explain future rating downgrades combine information contained in both income statements and balance sheets : 
the change in the return on equity $(\triangle \mathrm{ROE})$ for horizons ranging from 2 to 4 terms and the change in the implicit interest margin variable ( $\triangle$ INTAP) for the shortest horizon.

\subsection{Additional contribution of market indicators}

To assess the specific additional contribution of market indicators, each accounting information based model obtained in table 7 is augmented with market indicators. Table 8 shows the estimation results which contain only the market indicators that "survived" to the stepwise selection procedure when added to the optimal subset of accounting indicators. In this sense this procedure is based on the assumption that market information is not only a substitute to accounting information but also conveys additional information which contributes to improve the prediction of future downgrades.

The results in table 8 show that, all the coefficients have the expected sign and that among our large set of potential market indicators the LNP variable significantly improves predictions in the 4 models. Moreover, the degree of significance of this market indicator increases with the prediction horizon which suggests that this variable is more efficient in predicting events four quarters ahead ${ }^{7}$. A possible explanation is that market indicators react well ahead prior to a downgrade (4 quarters) and consequently the market is less likely to react heavily just before the actual "punishment" date (1 quarter). Up to this stage our results are thus in line with those obtained in previous research. Moreover, our stepwise procedure lead to the selection of the simplest and less costly indicator. Particularly, the distance-todefault variable adds less information than a variable simply capturing significant changes in stock prices. Our findings are thus similar to the results obtained by Elmer and Fissel [2001], and Curry, Elmer and Fissel [2003] in the case of US banks who limit their investigation to price trends or excess return indicators. Our results do not support the use of a distance-todefault indicator as a leading indicator as shown by Gropp, Vesala and Vulpes [2005] for European banks ${ }^{8}$.

\footnotetext{
${ }^{7}$ Because we consider overlapping windows, the coefficient associated to LNP in model 1 can be interpreted as its ability to predict an event occurring at a mean horizon of 1.5 months (assuming that downgrades occur on February $\left.15^{\text {th }}\right)$. For model 2 this mean horizon can be be proxied by : $(15 * 1.5+14 * 4.5) / 29=2.9$ months $(15$ and 14 are the number of events occurring respectively on the first and second quarters). For models 3 and 4 the mean horizons are 4.02 and 6.53 months respectively.

${ }^{8}$ Because our setting accounts for downgrades by more than one rating agency this raises the issue of whether the stock market delivers a weaker signal when there is disagreement among agencies or whether the intensity of the market indicator signal is higher when all rating agencies agree on the opportunity of a downgrade. We address this question by defining a dummy variable CONSENSUS which takes the value of 1 if, at least, one of the two other rating agencies downgrades the same bank during the four months following the first sanction and 0 in any other case. Each model estimated in table 8 is then augmented with the interacting variable LNP *
} 
Table 8 : Financial deterioration :

Specific and additional contribution of market indicators

Model specification: $\operatorname{Prob}\left\{\mathrm{Y}_{\mathrm{i}}=1\right\}=\Phi\left(\alpha+\sum_{\mathrm{j}=1}^{\mathrm{J}} \beta_{\mathrm{j}} \mathrm{C}_{\mathrm{ji}}+\sum_{\mathrm{l}=1}^{\mathrm{L}} \gamma_{\mathrm{l}} \mathrm{M}_{\mathrm{li}}\right)$

\begin{tabular}{|c|c|c|c|c|c|}
\hline & & Model 1 & Model 2 & Model 3 & Model 4 \\
\hline \multicolumn{2}{|c|}{ Constant } & $\begin{array}{c}-2.823 * * * \\
(-8.337)\end{array}$ & $\begin{array}{c}-1.932 * * * \\
(-8.383)\end{array}$ & $\begin{array}{c}-1.638 * * * \\
(-8.191)\end{array}$ & $\begin{array}{c}-1.136^{* * *} * \\
(-6.955)\end{array}$ \\
\hline \multirow{2}{*}{ Earnings ratios } & $\triangle \mathrm{INTAP}$ & \multirow[t]{2}{*}{$\begin{array}{c}-1.925 * * * \\
(-2.924)\end{array}$} & & & \\
\hline & $\triangle \mathrm{ROE}$ & & $\begin{array}{c}-0.072 * * \\
(-2.193)\end{array}$ & $\begin{array}{l}-0.057^{*} \\
(-1.820)\end{array}$ & $\begin{array}{l}-0.042 * \\
(-1.697)\end{array}$ \\
\hline Market indicators & LNP & $\begin{array}{c}-4.057 * * \\
(-2.440)\end{array}$ & $\begin{array}{c}-3.700 * * * \\
(-2.732)\end{array}$ & $\begin{array}{c}-4.185 * * * \\
(-3.267)\end{array}$ & $\begin{array}{c}-4.347 * * * \\
(-3.931)\end{array}$ \\
\hline \multicolumn{2}{|c|}{ Mc Fadden $\mathrm{R}^{2}$} & 0.110 & 0.090 & 0.088 & 0.090 \\
\hline \multicolumn{2}{|c|}{ Number of observations } & 187 & 204 & 213 & 237 \\
\hline \multicolumn{2}{|c|}{ Number of cases $Y=1$} & 15 & 29 & 38 & 62 \\
\hline \multicolumn{2}{|c|}{$\chi^{2}$ statistic for $\gamma_{1}=0$} & $5.952 * *$ & $7.467 * * *$ & $10.672 * * *$ & $15.452 * * *$ \\
\hline
\end{tabular}

This table reports logit estimation results obtained with the dependent variable regressed on a constant, the accounting indicators previously selected and the market indicators selected by the stepwise process. Models 1 , 2, 3 and 4 explain downgradings occurring respectively in less than 1, 2, 3 and 4 quarters. Standard errors are adjusted using the Huber-White method. *, ** and *** indicate significance respectively at 10\%, 5\% and $1 \%$ levels. Z-statistics are shown in parenthesis. The number of observations differs in the different models because all data are not available for each bank, each year and each indicator. $\chi^{2}$ statistic refers to a likelihood ratio test for the null hypothesis of nullity of market indicator coefficients.

5.4. Size effect, opacity effect and the actual contribution of market based indicators

As discussed earlier in the paper, the contribution of market indicators to early detection of bank financial distress is a challenge to modern banking theory because theory assumes that banks acquire private information on borrowers which may be ignored by outsiders. Banking theory also insists on negative external effects induced by liquidity services offered by banks supporting the existence of public safety nets in practice for at least the largest banking institutions. In this sense the market may less react to changes in financial conditions for large institutions implying a lower contribution of market prices to predict future failure. Conversely, one could assume that the market mainly focuses on the largest institutions because information may be less reliable for smaller banks. Identically, bank opacity may also

CONSENSUS, in order to test for the null of the absence of higher predictive power of the market indicator in such a context. The results (see table A2 in appendix) show that the null is never rejected. 
affect the marginal contribution of market indicators. In the banking literature, private information is often captured by assessing the structure of financial statements. In theory, opacity comes from the intermediation function of banks and is often proxied by the ratio of loans to total assets. Since deposits are insured and deposit interest rates are not marked to market alternatively the ratio of deposits to total assets is also another frequently employed proxy. Conversely, large issues of non insured securities such as bonds or subordinated bonds (market funded liabilities) should induce market discipline hence contributing to improve the quality of the information conveyed by the market. Because liquidity is essential for market signals to transmit accurate information, the extent to which liabilities are market funded is crucial. Therefore the proportion of market funding on the liability side of the balance sheet is also considered as a determinant variable in several studies.

The size effect and the opacity effect are assessed by first estimating for each horizon an augmented model specified as follows :

$$
\operatorname{Prob}\left\{\mathrm{Y}_{\mathrm{i}}=1\right\}=\Phi\left(\alpha+\alpha^{\prime} \mathrm{D}_{\mathrm{i}}+\sum_{j=1}^{J} \beta_{j} C_{j i}+\sum_{l=1}^{L} \gamma_{l} M_{l i}+\sum_{l=1}^{L} \gamma_{l}{ }^{\prime} D_{i} M_{l i}\right)
$$

where $D_{i}$ is a dummy variable, capturing either the size effect $\left(\mathrm{DBIG}_{\mathrm{i}}\right)$ or the opacity effect $\left(\mathrm{DOPAC}_{\mathrm{i}}\right)$. Two tests are then conducted first to determine the effectiveness of each effect $\left(\mathrm{H}_{0}: \alpha^{\prime}=0\right.$ and $\left.\gamma_{1}^{\prime}=0 \forall 1\right)$ and then to assess the assumption that size or opacity outweighs or neutralizes the predictive power of each market indicator $\left(\mathrm{H}_{0}: \gamma_{1}+\gamma^{\prime}{ }_{1}=0 \forall 1\right)$.

\subsubsection{Size effect}

Tables 9 shows the results obtained for the size effect. DBIG is a binary variable which equals 1 if total bank assets are higher than 300 billion euros (a significant threshold in our sample asset size distribution) or if the considered bank is the first or second largest bank in its country ranking; otherwise it equals 0 . On the basis of the first criterion (asset size) we checked that every bank with a total asset value above 300 billion euros was assigned a Fitch Support rating equal to 1 . This support rating indicates the likelihood of public or private support on a scale from 1 to 4 ; a grade of 1 (the highest) indicates the presence of an assured legal guarantee. The second criterion (country ranking) was introduced because banks which may be considered as relatively small in our sample may benefit from a major position in their domestic banking system. An alternative way to construct the binary variable is to solely consider the Fitch Support rating (Gropp, Vesala and Vulpes [2005] used ratings 1 and 2 to identify too-big-to-fail banks but in a different setting). However, this rating was not reported 
for all the banks in our sample throughout the studied period ${ }^{9}$. Also, the use of a continuous variable such as the log of total assets, which is common in the empirical literature, is irrelevant in the case of our cross European analysis because it would not render country specific characteristics (size difference of the largest banks in each banking system, institutional arrangements...).

Table 9 : Contribution of market indicators and bank size Model specification : $\operatorname{Prob}\left\{\mathrm{Y}_{\mathrm{i}}=1\right\}=\Phi\left(\alpha+\alpha^{\prime} \mathrm{DBIG}_{\mathrm{i}}+\sum_{\mathrm{j}=1}^{\mathrm{J}} \beta_{\mathrm{j}} \mathrm{C}_{\mathrm{ji}}+\sum_{\mathrm{l}=1}^{\mathrm{L}} \gamma_{1} \mathrm{M}_{\mathrm{li}}+\sum_{\mathrm{l}=1}^{\mathrm{L}} \gamma_{1}^{\prime}\left(\mathrm{DBIG}_{\mathrm{i}} \times \mathrm{M}_{\mathrm{li}}\right)\right.$

\begin{tabular}{|c|c|c|c|c|}
\hline & Model 1 & Model 2 & Model 3 & Model 4 \\
\hline Constant & $\begin{array}{c}-3.410^{* * *} \\
(-7.091)\end{array}$ & $\begin{array}{c}-2.275^{* * *}(-7.833)\end{array}$ & $\begin{array}{c}-1.876^{* * *} \\
(-7.669)\end{array}$ & $\begin{array}{c}-1.216^{* * *} \\
(-6.479)\end{array}$ \\
\hline DBIG & $\begin{array}{l}1.098 \\
(1.480)\end{array}$ & $\begin{array}{l}1.019^{* *} \\
(2.281)\end{array}$ & $\begin{array}{l}0.759^{*} \\
(1.850)\end{array}$ & $\begin{array}{c}0.260 \\
(0.698)\end{array}$ \\
\hline$\triangle$ INTAP & $\begin{array}{c}-2.518^{* * *} \\
(-3.435)\end{array}$ & & & \\
\hline$\triangle \mathrm{ROE}$ & & $\begin{array}{l}-0.068^{*} \\
(-1.932)\end{array}$ & $\begin{array}{l}-0.055^{*} \\
(-1.722)\end{array}$ & $\begin{array}{l}-0.042^{*} \\
(-1.690)\end{array}$ \\
\hline LNP & $\begin{array}{c}-1.493 \\
(-1.069)\end{array}$ & $\begin{array}{c}-2.851 \\
(-1.541)\end{array}$ & $\begin{array}{c}-3.303 * * \\
(-2.060)\end{array}$ & $\begin{array}{c}-3.413 * * * \\
(-2.686)\end{array}$ \\
\hline $\mathrm{LNP} \times \mathrm{DBIG}$ & $\begin{array}{c}-7.870 * * \\
(-2.332)\end{array}$ & $\begin{array}{c}-2.174 \\
(-0.790)\end{array}$ & $\begin{array}{l}-2.456 \\
(-0.927)\end{array}$ & $\begin{array}{c}-3.336 \\
(-1.376)\end{array}$ \\
\hline Mc Fadden $\mathrm{R}^{2}$ & 0.211 & 0.130 & 0.114 & 0.101 \\
\hline Total number of observations & 187 & 204 & 213 & 237 \\
\hline Number of observations of type $Y=1$ & 15 & 29 & 38 & 62 \\
\hline Risk level to reject : $\alpha^{\prime}=0$ et $\gamma_{1}^{\prime}=0 \forall 1$ & $0.08 \% * * *$ & $1.54 \% * *$ & $7.92 \% *$ & $22.04 \%$ \\
\hline Risk level to reject : $\gamma_{1}+\gamma_{1}^{\prime}=0 \forall 1$ & $0.27 \% * * *$ & $1.42 \% * *$ & $0.63 \% * * *$ & $0.11 \% * * *$ \\
\hline
\end{tabular}

This table reports logit estimation results obtained with the dependent variable regressed on a constant, the accounting indicators and the market indicators previously selected. Size effect is taken into account with a dummy variable (DBIG) associated with the constant and the market indicators. DBIG is equal to 1 if bank's total assets is greater than 300 billions of euros or if the bank is ranked first or second in its country, and 0 otherwise. Models 1, 2, 3 and 4 explain downgradings occurring respectively in less than 1, 2, 3 and 4 quarters. Standard errors are adjusted using the Huber-White method. *, ** and *** indicate significance respectively at $10 \%, 5 \%$ and $1 \%$ levels. Z-statistics are shown in parenthesis. The number of observations differs in the different models because all data are not available for each bank, each year and each indicator.

The results show that for relatively smaller banks LNP is no longer significant for the shortest horizons (model 1 and model 2). The tests (two last rows of table 9) show that the size effect decreases with the horizon length and that the size effect increases the predictive power of LNP on the shortest horizon. We checked for the robustness of these results by running our stepwise method separately on our two samples of small and large banks. The results, which are not presented here, but available upon request, showed that all our market

\footnotetext{
${ }^{9}$ Based on Fitch Support ratings displayed in Bankscope at the end of 2002, our two criteria enable us to capture all the banks with a Support rating $=1$ and 10 out of the 17 banks with a Support rating $=2$.
} 
indicators were rejected (no significant additional prediction value) for the sample of small banks in model 1 whereas LNP was highly significant in improving the prediction of future downgrades for the sample of large banks, for every horizon. On the whole, whereas Gropp, Vesala and Vulpes [2005] show that safety net issues do not alter the predictive power of market indicators, suggesting that stockholders do not expect to be rescued along with debtholders in case of default, our results are more mitigated. Instead of underlining the lack of reaction (or the less significant reaction) of large banks' stock prices (too-big-to fail effect) we present evidence, for the two first horizons, that a decrease in asset size may undermine the ability of stock prices to transmit useful information on future bank financial health.

\subsubsection{Opacity effect}

Several definitions of the binary variable DOPAC were considered to study the link between the degree of bank opacity and the predictive power of market variables. We considered the ratio of Net Loans to Total Assets, the ratio of Deposits to Total Assets, the ratio of Subordinated Debt to Total Assets, and the ratio of Market Funded Liabilities to Total Assets ${ }^{10}$. Only the results obtained with the ratio of Deposits to Total Assets and the ratio of Market Funded Liabilities to Total Assets are conclusive in discriminating the predictive power of market variables in a very similar way. Therefore we solely report in table 10 the results obtained when DOPAC equals 1 if the ratio of market funded liabilities is lower than its median (equal to $25.63 \%)^{11}$. Market funded liabilities are measured as : Total Assets Deposits - Total Equity.

The results in table 10 show that the significance of both LNP and LNPxDOPAC increases with the prediction horizon and reaches the $1 \%$ level in model 4 which suggests that opacity is more likely to alter the predictive power of market variables for the longest horizons. In almost all cases (models 2, 3, 4) the coefficient of LNP and the coefficient of the interacting indicator LNPXDOPAC are of opposite sign and significant. Therefore a higher degree of opacity tends to weaken the existing link between market indicators and the probability of a future downgrade. Based on the results of the $\gamma_{1}+\gamma_{1}^{\prime}=0$ test, the predictive power of market indicators is totally outweighed by bank opacity, a result which holds for the 4 models and which is also confirmed by conducting the stepwise process on the sample of opaque banks showing (see table A3 in appendix) that none of our market indicators can predict downgrades

\footnotetext{
${ }^{10}$ One can refer to Goyeau, Sauviat and Tarazi (2001) and Crouzille, Lepetit and Tarazi (2004) for a discussion on the use of these ratios as private information proxies.
} 
for such banks. A similar result (see table A4 in appendix) is obtained when the dummy variable is constructed on the basis of the ratio of Deposits to Total Assets ${ }^{12}$. However, tests conducted with the subordinated debt ratio were not conclusive indicating that the predictive power of market variables is independent of the amount of subordinated debt issued by banks.

Table 10 : Contribution of market indicators and bank opacity

Model specification : $\operatorname{Prob}\left\{\mathrm{Y}_{\mathrm{i}}=1\right\}=\Phi\left(\alpha+\alpha^{\prime} \mathrm{DOPAC}_{\mathrm{i}}+\sum_{\mathrm{j}=1}^{\mathrm{J}} \beta_{\mathrm{j}} \mathrm{C}_{\mathrm{ji}}+\sum_{\mathrm{l}=1}^{\mathrm{L}} \gamma_{1} \mathrm{M}_{\mathrm{li}}+\sum_{\mathrm{l}=1}^{\mathrm{L}} \gamma_{1}^{\prime} \mathrm{DOPAC}_{\mathrm{i}} \times \mathrm{M}_{\mathrm{li}}\right)$

\begin{tabular}{|c|c|c|c|c|}
\hline & Model 1 & Model 2 & Model 3 & Model 4 \\
\hline CONSTANT & $\begin{array}{c}-2.720 * * * \\
(-6.563)\end{array}$ & $\begin{array}{c}-1.454 * * * \\
(-4.990)\end{array}$ & $\begin{array}{c}-1.185 * * * \\
(-4.568)\end{array}$ & $\begin{array}{c}-0.612 * * * \\
(-2.845)\end{array}$ \\
\hline DOPAC & $\begin{array}{c}-0.290 \\
(-0.519)\end{array}$ & $\begin{array}{c}-1.140 * * \\
(-2.504)\end{array}$ & $\begin{array}{c}-1.085 * * * \\
(-2.669)\end{array}$ & $\begin{array}{c}-1.357 * * * \\
(-3.844)\end{array}$ \\
\hline$\triangle I N T A P$ & $\begin{array}{c}-1.978 * * * \\
(-3.095)\end{array}$ & & & \\
\hline$\triangle \mathrm{ROE}$ & & $\begin{array}{c}-0.080 * * \\
(-2.523)\end{array}$ & $\begin{array}{c}-0.069 * * \\
(-2.293)\end{array}$ & $\begin{array}{c}-0.054 * * \\
(-2.212)\end{array}$ \\
\hline LNP & $\begin{array}{l}-5.074 * \\
(-1.927)\end{array}$ & $\begin{array}{c}-4.74 * * * \\
(-2.767)\end{array}$ & $\begin{array}{c}-5.426 * * * \\
(-3.076)\end{array}$ & $\begin{array}{c}-5.596 * * * \\
(-3.707)\end{array}$ \\
\hline LNP $\times$ DOPAC & $\begin{array}{c}4.026 \\
(1.266) \\
\end{array}$ & $\begin{array}{c}4.798 * * \\
(2.193) \\
\end{array}$ & $\begin{array}{c}5.063 * * \\
(2.258) \\
\end{array}$ & $\begin{array}{c}5.970 * * * \\
(2.899)\end{array}$ \\
\hline Mc Fadden $\mathrm{R}^{2}$ & 0.127 & 0.150 & 0.149 & 0.177 \\
\hline Total number of observations & 187 & 204 & 213 & 237 \\
\hline Number of observations of type $\mathrm{Y}=1$ & 15 & 29 & 38 & 62 \\
\hline Risk level to reject : $\alpha^{\prime}=0$ et $\gamma_{1}^{\prime}=0 \forall 1$ & $37.11 \%$ & $0.31 \% * * *$ & $0.17 \% * * *$ & $0.00 \% * * *$ \\
\hline Risk level to reject : $\gamma_{1}+\gamma_{1}^{\prime}=0 \forall 1$ & $56.49 \%$ & $96.83 \%$ & $79.51 \%$ & $79.01 \%$ \\
\hline
\end{tabular}

This table reports logit estimation results obtained with the dependent variable regressed on a constant, the accounting indicators and the market indicators previously selected. Opacity effect is taken into account with a dummy variable (DOPAC) associated with the constant and the market indicators. DOPAC is equal to 1 if the value of the ratio market funded liabilities / total assets is lower than its median (25.63\%), and 0 otherwise. Models 1, 2, 3 and 4 explain downgradings occurring respectively in less than 1, 2, 3 and 4 quarters. Standard errors are adjusted using the Huber-White method. *, ** and *** indicate significance respectively at $10 \%, 5 \%$ and $1 \%$ levels. Z-statistics are shown in parenthesis. The number of observations differs in the different models because all data are not available for each bank, each year and each indicator.

\footnotetext{
${ }^{11}$ See table A4 in appendix for results obtained with the ratio Deposits / Total Assets. The other results are available from the authors upon request.

${ }^{12}$ This neutralization effect is in line with the results obtained by Billett, Garfinkel and O'Neal (1998) who show that Moody's downgrades are associated with negative abnormal returns which are increasing in the bank's reliance on insured deposits. To check for consistency, we tested for market reaction following a downgrade for two different samples of banks by regressing the dependent variable on LNP (measured either on December $31^{\text {st }}$ preceding the event or on December $31^{\text {st }}$ following the event). The results show (see table A5 in appendix) that for banks weakly reliant on deposits the market significantly reacts only after the event. For other banks, the market reacts both before and after the event but the reaction before the event is stronger (higher coefficients (in absolute value) and higher significance levels).
} 
To check for robustness, the augmented models 1 to 4 were also estimated on 4 different panels of banks on the basis of the structure of their balance sheets (table 11) to isolate the impact of marked to market assets and liabilities. Panel A consists of banks exhibiting a high degree of loan activity (low proportion of marked to market assets) weakly funded by insured deposits (high proportion of market funded liabilities); 2/ Panel B is limited to banks with a relatively high proportion of loans and weakly reliant on market debt; 3 / Panel C contains banks with a low loan activity funded to a large extent with insured deposits; 4/ Panel D is relative to banks with a low degree of loan activity mainly funded with market debt. More precisely, 2 criteria are taken into account to discriminate banks : the ratio of net loans to total assets (the extent to which assets are not marked to market) and the ratio of market funded liabilities to total assets (the extent to which a bank relies on insured and non marked to market liabilities). The medians of both ratios were used to define the 4 panels ( $25.63 \%$ for the ratio of market funded liabilities and $54.32 \%$ for the loan ratio).

Our main objective here is to assess the extent to which abundant market debt is likely to induce changes in the opacity of bank assets. In other words, does the predictive power of market indicators solely depend on the structure of bank liabilities (amount of market debt)? Are market participants (who should have strong incentives to discipline heavily market funded banks) able to process information when bank assets are, to a large extent, not market priced? The results in table 11 show that market indicators are powerful to predict future downgrades as long as the proportion of market debt in bank liabilities is relatively high, independently of the percentage of loans in bank assets (panels A and D). Moreover, when the proportion of (uninsured) market debt is low (panels B and C) market indicators tend to loose their predictive power which confirms the results obtained in table 10. This result holds for any asset profile (proportion of loans) and thus for any degree of transparency of the asset side of the balance sheet.

Moreover, this result is unchanged with respect to the amount of subordinated debt issued by banks : when banks are heavily reliant on insured and non market priced deposits, larger subordinated debt issues do not contribute to improve prediction (left hand side of table $\left.12, \mathrm{H}_{0}: \gamma_{1}=0 \forall 1\right)$. Conversely, the results obtained in the right hand side of table $12\left(\mathrm{H}_{0}: \gamma_{1}=\right.$ $0 \forall 1$ ) show that larger subordinated debt issues significantly reinforce the role of market indicators when bank liabilities are to a large extent market based (low proportion of insured deposits in the balance sheet). 


\section{Conclusion}

The objective of this paper was to assess the extent to which stock market prices can contribute to improve the prediction of future bank financial distress and thus to question the role and effectiveness of market discipline in the banking industry. By implementing a logit econometric model specifically designed for European banks we tested for the additional contribution of market based indicators (relatively to public financial statements) using a large set of accounting and stock market indicators. Whereas some of our results support the use of market related indicators (in line with those previously obtained in the literature), we show that the accuracy of the predictive power is dependent on the extent to which bank liabilities are market traded. For banks which heavily rely on (insured) deposits, the market seems unable to convey useful information and the amount of subordinated debt issued by banks does not contribute to any improvement in the expected link. 
Table 11 : Degree of securitization of assets and liabilities and contribution of market indicators

Model specification: $\operatorname{Prob}\left\{\mathrm{Y}_{\mathrm{i}}=1\right\}=\Phi\left(\alpha_{\mathrm{i}}+\sum_{\mathrm{j}=1}^{\mathrm{J}} \beta_{\mathrm{j}} \mathrm{C}_{\mathrm{ji}}+\sum_{\mathrm{l}=1}^{\mathrm{L}} \gamma_{1} \mathrm{M}_{\mathrm{li}}\right)$

\begin{tabular}{|c|c|c|c|c|c|c|c|c|c|c|c|c|c|c|c|c|}
\hline & \multicolumn{4}{|c|}{$\begin{array}{l}\text { Panel A : (net loans/ total assets) high and } \\
\text { (market funded liabilities/ total liabilities) high }\end{array}$} & \multicolumn{4}{|c|}{$\begin{array}{l}\text { Panel B : (net loans/ total assets) high and } \\
\text { (market funded liabilities/ total liabilities) low }\end{array}$} & \multicolumn{4}{|c|}{$\begin{array}{l}\text { Panel C : (net loans/ total assets) low and } \\
\text { (market funded liabilities/ total liabilities) low }\end{array}$} & \multicolumn{4}{|c|}{$\begin{array}{l}\text { Panel D : (net loans/ total assets) low and } \\
\text { (market funded liabilities/ total liabilities) high }\end{array}$} \\
\hline & Model 1 & Model 2 & Model 3 & Model 4 & Model 1 & Model 2 & Model 3 & Model 4 & Model 1 & Model 2 & Model 3 & Model 4 & Model 1 & Model 2 & Model 3 & Model 4 \\
\hline Constant & $\begin{array}{c}-3.169 \\
* * * \\
(-2.788)\end{array}$ & $\begin{array}{l}-2.097 * * * \\
(-3.531)\end{array}$ & $\begin{array}{c}-1.629 * * * \\
(-3.439)\end{array}$ & $\begin{array}{c}-0.688 * * \\
(-1.986)\end{array}$ & $\begin{array}{l}-3.405 * * * \\
(-4.777)\end{array}$ & $\begin{array}{l}-2.861 * * * \\
(-5.175)\end{array}$ & $\begin{array}{c}-2.418 * * * \\
(-5.445)\end{array}$ & $\begin{array}{l}-2.304 * * * \\
(-5.399)\end{array}$ & $\begin{array}{l}-2.555^{* * *} \\
(-4.408)\end{array}$ & $\begin{array}{l}-2.250 * * * \\
(-4.430)\end{array}$ & $\begin{array}{l}-2.171 * * * \\
(-4.197)\end{array}$ & $\begin{array}{c}-1.790 * * * \\
(-4.354)\end{array}$ & $\begin{array}{c}-3.182 * * * \\
(-4.682)\end{array}$ & $\begin{array}{c}-1.196 * * * \\
(-3.168)\end{array}$ & $\begin{array}{c}-0.934 \\
* * * \\
(-2.826)\end{array}$ & $\begin{array}{l}-0.576 * \\
(-1.954)\end{array}$ \\
\hline$\triangle \mathrm{INTAP}$ & $\begin{array}{c}-2.717 \\
(-1.426)\end{array}$ & & & & $\begin{array}{l}-1.787 \\
(-1.207)\end{array}$ & & & & $\begin{array}{c}-0.989 \\
(-0.716)\end{array}$ & & & & $\begin{array}{l}-3.382 * * * * \\
(-3.940)\end{array}$ & & & \\
\hline$\triangle \mathrm{ROE}$ & & $\begin{array}{c}-0.061 \\
(-0.929)\end{array}$ & $\begin{array}{c}-0.027 \\
(-0.431)\end{array}$ & $\begin{array}{c}-0.049 \\
(-0.874)\end{array}$ & & $\begin{array}{c}-0.038 \\
(-0.322)\end{array}$ & $\begin{array}{l}0.058 \\
(0.447)\end{array}$ & $\begin{array}{c}0.073 \\
(0.640)\end{array}$ & & $\begin{array}{c}-0.011 \\
(-0.094)\end{array}$ & $\begin{array}{c}-0.046 \\
(-0.522)\end{array}$ & $\begin{array}{c}-0.004 \\
(-0.051)\end{array}$ & & $\begin{array}{c}-0.097 * * * \\
(-3.013)\end{array}$ & $\begin{array}{l}-0.091 * * * \\
(-2.774)\end{array}$ & $\begin{array}{c}-0.076 * * * * \\
(-2.592)\end{array}$ \\
\hline LNP & $\begin{array}{l}-12.021 * * \\
(-2.328)\end{array}$ & $\begin{array}{l}-9.004 * * * \\
(-3.001)\end{array}$ & $\begin{array}{c}-7.559 * * * \\
(-2.851)\end{array}$ & $\begin{array}{c}-6.424 * * * \\
(-2.938)\end{array}$ & $\begin{array}{c}2.358 \\
(0.915)\end{array}$ & $\begin{array}{c}2.503 \\
(1.113)\end{array}$ & $\begin{array}{c}2.873 \\
(1.380)\end{array}$ & $\begin{array}{l}4.725^{*} \\
(1.905)\end{array}$ & $\begin{array}{c}-2.885 \\
(-1.251)\end{array}$ & $\begin{array}{c}-2.249 \\
(-1.297)\end{array}$ & $\begin{array}{c}-2.757 \\
(-1.514)\end{array}$ & $\begin{array}{l}-3.237^{*} \\
(-1.817)\end{array}$ & $\begin{array}{c}-4.720 * * \\
(-2.330)\end{array}$ & $\begin{array}{l}-3.879^{*} \\
(-1.940)\end{array}$ & $\begin{array}{c}-5.139 * * \\
(-2.230)\end{array}$ & $\begin{array}{c}-5.263 * * \\
(-2.380)\end{array}$ \\
\hline $\begin{array}{c}\text { Mc Fadden } \\
\mathrm{R}^{2}\end{array}$ & 0.234 & 0.193 & 0.140 & 0.157 & 0.043 & 0.018 & 0.021 & 0.054 & 0.034 & 0.018 & 0.049 & 0.033 & 0.318 & 0.191 & 0.205 & 0.183 \\
\hline $\begin{array}{c}\text { Total } \\
\text { number of } \\
\text { observations }\end{array}$ & 34 & 39 & 41 & 55 & 61 & 62 & 64 & 66 & 51 & 53 & 54 & 56 & 41 & 50 & 54 & 60 \\
\hline $\begin{array}{c}\text { Number of } \\
\text { observations } \\
\text { with } Y=1\end{array}$ & 4 & 7 & 9 & 23 & 3 & 4 & 6 & 8 & 4 & 5 & 6 & 8 & 4 & 13 & 17 & 23 \\
\hline
\end{tabular}

This table reports logit estimation results obtained with the dependent variable regressed on a constant, the accounting indicators and the market indicators previously selected. Four subsamples are taken into account on the basis of two ratios; net loans/total assets and market funded liabilities/ total liabilities. These ratios are considered high if their value is higher than the median (25.63\% for market funded liabilities/ total liabilities and 54.32\% for net loans/total assets). Models 1, 2, 3 and 4 explain downgradings occurring respectively in less than 1, 2, 3 and 4 quarters. Standard errors are adjusted using the Huber-White method. *, ** and *** indicate significance respectively at 10\%, 5\% and 1\% levels. Z-statistics are shown in parenthesis. 
Table 12: Structure of bank liabilities, subordinated debt and contribution of market

$$
\text { indicators }
$$

Model specification:

$$
\operatorname{Prob}\left\{Y_{\mathrm{i}}=1\right\}=\Phi\left(\alpha+\alpha^{\prime} \operatorname{DUMSUBA}_{\mathrm{i}}+\sum_{\mathrm{j}=1}^{\mathrm{J}} \beta_{\mathrm{j}} \mathrm{C}_{\mathrm{ji}}+\sum_{\mathrm{l}=1}^{\mathrm{L}} \gamma_{\mathrm{l}} \mathrm{M}_{\mathrm{li}}+\sum_{\mathrm{l}=1}^{\mathrm{L}} \gamma_{1}^{\prime} \mathrm{DUMSUBA}_{\mathrm{i}} \times \mathrm{M}_{\mathrm{li}}\right)
$$

Test of the null hypothesis of absence of predictive contribution of market indicators when the ratio subordinated debt/ total assets is lower than its median, $\mathrm{H}_{0}: \gamma_{1}+\gamma_{1}^{\prime}=0 \forall 1$

Test of the null hypothesis of absence of predictive contribution of market indicators when the ratio

\begin{tabular}{|c|c|c|c|c|c|c|c|c|}
\hline & \multicolumn{4}{|c|}{ Sample with high ratio of deposits/ total assets } & \multicolumn{4}{|c|}{ Sample with low ratio of deposits/ total assets } \\
\hline & Model 1 & Model 2 & Model 3 & Model 4 & Model 1 & Model 2 & Model 3 & Model 4 \\
\hline Constant & $\begin{array}{c}-3.645 * * * \\
(-3.258)\end{array}$ & $\begin{array}{c}-2.008 * * * \\
(-3.843)\end{array}$ & $\begin{array}{c}-1.657 * * * \\
(-3.654)\end{array}$ & $\begin{array}{c}-1.446 * * * \\
(-3.391)\end{array}$ & $\begin{array}{c}-3.221 * * * \\
(-4.402)\end{array}$ & $\begin{array}{c}-2.811 * * * \\
(-3.143)\end{array}$ & $\begin{array}{c}-2.279 * * * \\
(-3.445)\end{array}$ & $\begin{array}{c}-0.956 * * \\
(-2.335)\end{array}$ \\
\hline$\triangle I N T A P$ & $\begin{array}{c}-1.194 \\
(-0.947)\end{array}$ & & & & $\begin{array}{c}-2.962 * * * \\
(-2.486)\end{array}$ & & & \\
\hline$\triangle \mathrm{ROE}$ & & $\begin{array}{c}0.068 \\
(0.832)\end{array}$ & $\begin{array}{c}0.040 \\
(0.495)\end{array}$ & $\begin{array}{c}0.076 \\
(0.994)\end{array}$ & & $\begin{array}{c}-0.101 * * * \\
(-3.364)\end{array}$ & $\begin{array}{c}-0.092 * * * \\
(-3.208)\end{array}$ & $\begin{array}{c}-0.075 * * * \\
(-2.810)\end{array}$ \\
\hline DUMSUBA & $\begin{array}{c}0.607 \\
(0.543)\end{array}$ & $\begin{array}{c}-0.425 \\
(-0.655)\end{array}$ & $\begin{array}{c}-0.647 \\
(-1.096)\end{array}$ & $\begin{array}{c}-0.563 \\
(-1.015)\end{array}$ & $\begin{array}{c}-0.417 \\
(-0.411)\end{array}$ & $\begin{array}{l}1.586 * \\
(1.668)\end{array}$ & $\begin{array}{l}1.269 \% \\
(1.709)\end{array}$ & $\begin{array}{c}0.444 \\
(0.862)\end{array}$ \\
\hline LNP & $\begin{array}{c}-1.285 \\
(-1.287)\end{array}$ & $\begin{array}{c}-2.639 \\
(-1.175)\end{array}$ & $\begin{array}{c}-3.669 \\
(-1.596)\end{array}$ & $\begin{array}{l}-3.160 \\
(-1.465)\end{array}$ & $\begin{array}{l}-4.578 * \\
(-1.787)\end{array}$ & $\begin{array}{c}-11.683 * * * \\
(-3.027)\end{array}$ & $\begin{array}{c}-12.619 * * * \\
(-3.439)\end{array}$ & $\begin{array}{c}-7.936 * * * \\
(-2.972)\end{array}$ \\
\hline $\begin{array}{c}\text { LNP } \times \\
\text { DUMSUBA }\end{array}$ & $\begin{array}{c}2.859 \\
(0.782)\end{array}$ & $\begin{array}{c}2.536 \\
(0.749)\end{array}$ & $\begin{array}{c}4.657 \\
(1.363)\end{array}$ & $\begin{array}{c}4.604 \\
(1.282)\end{array}$ & $\begin{array}{l}-6.550 \\
(-1.585)\end{array}$ & $\begin{array}{c}7.103 \\
(1.608)\end{array}$ & $\begin{array}{l}\text { 7.868* } \\
(1.857)\end{array}$ & $\begin{array}{c}2.641 \\
(0.778)\end{array}$ \\
\hline $\begin{array}{c}\text { Mc Fadden } \\
\mathrm{R}^{2}\end{array}$ & 0.029 & 0.020 & 0.032 & 0.033 & 0.330 & 0.265 & 0.241 & 0.196 \\
\hline $\begin{array}{l}\text { Total number } \\
\text { of } \\
\text { observations }\end{array}$ & 106 & 111 & 114 & 118 & 73 & 80 & 85 & 104 \\
\hline $\begin{array}{c}\text { Number of } \\
\text { observations } \\
\text { with } Y=1\end{array}$ & 5 & 10 & 13 & 17 & 10 & 17 & 22 & 41 \\
\hline $\begin{array}{l}\text { Risk level to } \\
\text { reject : } \gamma_{1}+\gamma_{1}^{\prime} \\
=0 \forall 1\end{array}$ & $65.34 \%$ & $96.97 \%$ & $70.03 \%$ & $62.22 \%$ & $0.08 \% * * *$ & $4.12 \% * *$ & $2.82 \% * *$ & $0.53 \% * * *$ \\
\hline
\end{tabular}
subordinated debt/ total assets is higher than its median, $\mathrm{H}_{0}: \gamma_{1}=0 \forall 1$

This table reports logit estimation results obtained with the dependent variable regressed on a constant, the accounting indicators and the market indicators previously selected. Two sub-samples are taken into account depending on the value of the ratio deposits/ total assets. This ratio is considered high if it is higher than the median (67.57\%). The dummy variable DUMSUBA associated with the constant and the market indicators is equal to 1 if the value of the ratio subordinated debt/ total assets is lower than its median (1.51\%). Models 1, 2, 3 and 4 explain downgradings occurring respectively in less than 1, 2, 3 and 4 quarters. Standard errors are adjusted using the Huber-White method. *, ** and *** indicate significance respectively at 10\%, 5\% and $1 \%$ levels. Z-statistics are shown in parenthesis. The last line of the table gives the levels of risk to reject the null hypothesis of absence of predictive contribution of market indicators when the ratio subordinated debt/ total assets is lower than $1.51 \%$. 


\section{APPENDIX}

\section{Table A1}

Financial deterioration and early indicators

Simple regressions / closed windows

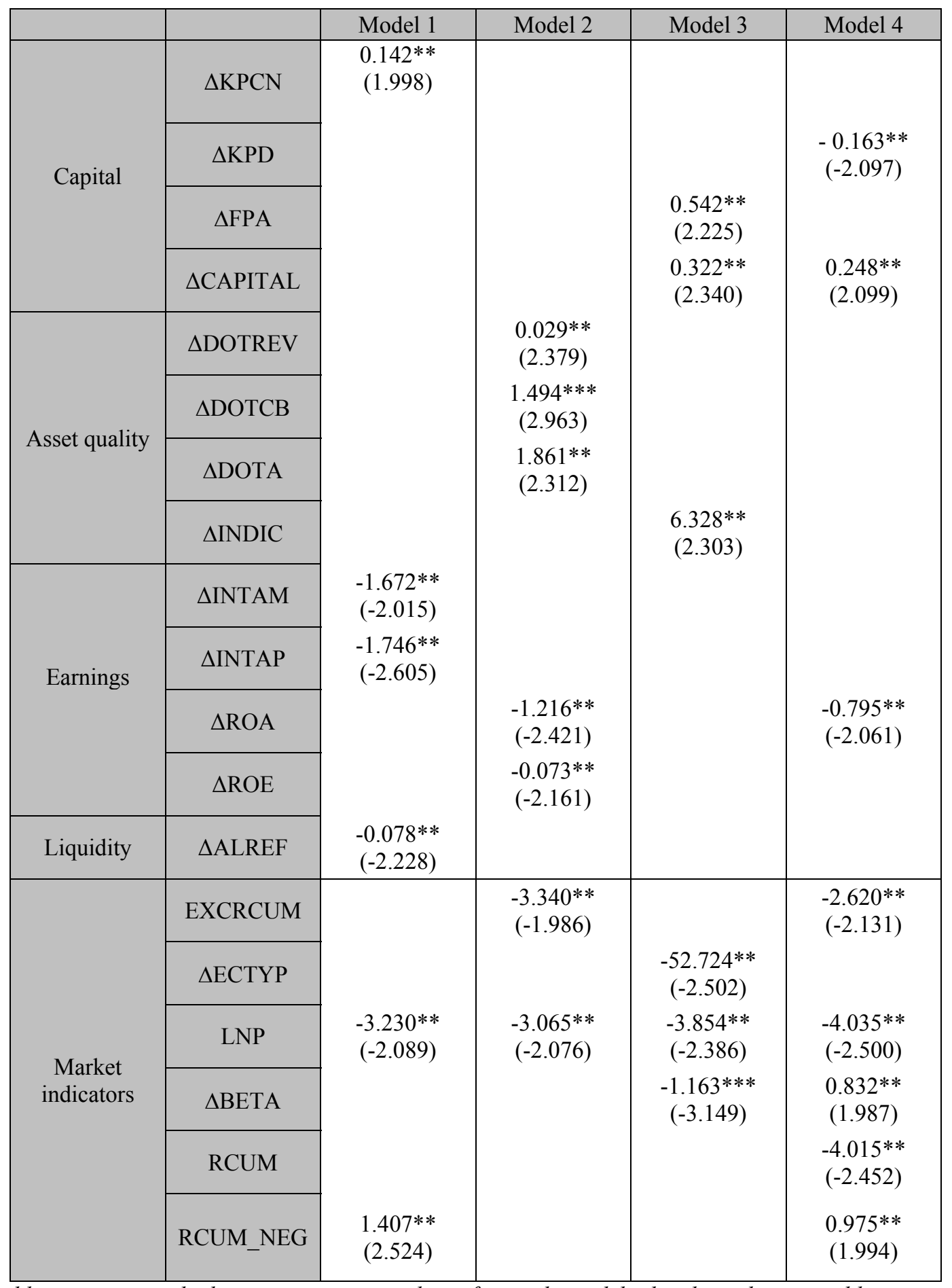

This table reports simple logit estimation results : for each model, the dependent variable is separately regressed on each explanatory variable and a constant. Models 1, 2, 3 and 4 explain downgradings (whatever their extent) occurring respectively in the $1^{\text {rst }}, 2^{\text {nd }}, 3^{\text {rd }}$ and $4^{\text {rd }}$ quarters. Standard errors are adjusted using the Huber-White method. ${ }^{*}, * *$ and $* * *$ indicate significance respectively at $10 \%, 5 \%$ and $1 \%$ levels. Z-statistics are shown in parenthesis. 


\section{Table A2}

Is the predictive power of market indicators increasing when rating agencies agree on the opportunity of downgrading the same bank?

\begin{tabular}{|c|c|c|c|c|c|}
\hline & & Model 1 & Model 2 & Model 3 & Model 4 \\
\hline \multicolumn{2}{|c|}{ Constant } & & $\begin{array}{c}-1.989 * * * \\
(-8.094)\end{array}$ & $\begin{array}{c}-1.703 * * * \\
(-7.944)\end{array}$ & $\begin{array}{c}-1.184 * * * \\
(-6.882)\end{array}$ \\
\hline \multirow{2}{*}{ Earnings ratios } & $\triangle I N T A P$ & & & & \\
\hline & $\Delta \mathrm{ROE}$ & & $\begin{array}{c}-0.068 * * \\
(-2.086)\end{array}$ & $\begin{array}{c}-0.048 \\
(-1.485)\end{array}$ & $\begin{array}{l}-0.035 * \\
(-1.335)\end{array}$ \\
\hline \multirow{2}{*}{ Market indicators } & LNP & & $\begin{array}{c}-2.686 * * \\
(-2.051)\end{array}$ & $\begin{array}{l}-3.245 * * \\
(-2.564)\end{array}$ & $\begin{array}{c}-3.814 * * * \\
(-3.440)\end{array}$ \\
\hline & LNP*CONSENSUS & & $\begin{array}{l}-12.961 \\
(-0.924)\end{array}$ & $\begin{array}{l}-16.207 \\
(-1.100)\end{array}$ & $\begin{array}{l}-15.512 \\
(-1.056)\end{array}$ \\
\hline \multicolumn{2}{|c|}{ Mc Fadden $\mathrm{R}^{2}$} & & 0.118 & 0.120 & 0.110 \\
\hline \multicolumn{2}{|c|}{ Number of observations } & & 204 & 213 & 237 \\
\hline \multicolumn{2}{|c|}{ Number of cases $Y=1$} & & 29 & 38 & 62 \\
\hline
\end{tabular}

CONSENSUS = 1 if, at least, one of the two other rating agencies downgraded the same bank in the four months following the first downgrade and 0 in any other cases. Model 1 could not be estimated ( insufficient number of observations). 


\section{Table A3}

\section{Contribution of market indicators and bank opacity}

Two Stages Stepwise

Sample : banks weakly reliant on market debt (ratio of market funded liabilities / total assets lower than its median $(25.63 \%)$

\begin{tabular}{|c|c|c|c|c|c|}
\hline & & Model 1 & Model 2 & Model 3 & Model 4 \\
\hline & Constant & $\begin{array}{c}-3.633 * * * \\
(-6.259)\end{array}$ & $\begin{array}{c}-2.584 * * * \\
(-5.904)\end{array}$ & $\begin{array}{c}-2.291 * * * \\
(-6.780)\end{array}$ & $\begin{array}{c}-2.556^{* * *} \\
(-5.554)\end{array}$ \\
\hline \multirow{3}{*}{ Capital } & $\triangle \mathrm{KPCN}$ & $\begin{array}{c}0.364 * * \\
(2.497)\end{array}$ & \multirow{3}{*}{$\begin{array}{l}-0.300 * * \\
(-2.266)\end{array}$} & \multirow{5}{*}{$\begin{array}{c}-0.306^{* *} \\
(-2.356)\end{array}$} & \multirow{4}{*}{$\begin{array}{l}-1.519 * \\
(-1.813)\end{array}$} \\
\hline & $\triangle \mathrm{KPD}$ & & & & \\
\hline & $\triangle \mathrm{KPA}$ & & & & \\
\hline & $\triangle \mathrm{PROVA}$ & & \multirow[t]{2}{*}{$\begin{array}{c}2.943 * * \\
(2.463)\end{array}$} & & \\
\hline Asset Quality & $\triangle \mathrm{INDIC}$ & & & & $\begin{array}{c}8.388 * * * \\
(2.762)\end{array}$ \\
\hline Earnings & & \multicolumn{4}{|c|}{ No One } \\
\hline Liquidity & $\triangle \mathrm{ALREF}$ & $\begin{array}{c}-0.210 * * * \\
(-3.327)\end{array}$ & & & \\
\hline $\begin{array}{c}\text { Market } \\
\text { Indicators }\end{array}$ & & \multicolumn{4}{|c|}{ No One } \\
\hline $\begin{array}{c}\text { Mc Fadden } \\
\text { R2 }\end{array}$ & & 0.275 & 0.212 & 0.083 & 0.152 \\
\hline $\begin{array}{l}\text { Total Number } \\
\text { of } \\
\text { Observations }\end{array}$ & & 97 & 91 & 119 & 87 \\
\hline $\begin{array}{c}\text { Number of } \\
\text { Observations } \\
\text { of Type } Y=1\end{array}$ & & 7 & 8 & 12 & 11 \\
\hline
\end{tabular}

This table reports logit estimation results obtained with the dependent variable regressed, in a first step, on a constant and the accounting indicators selected by the stepwise process. In a second step we tried to augment the models of the first step with a market indicator. Models 1, 2, 3 and 4 explain downgradings occurring respectively in less than 1, 2, 3 and 4 quarters. Standard errors are adjusted using the Huber-White method. *, $* *$ and $* * *$ indicate significance respectively at $10 \%, 5 \%$ and $1 \%$ levels. Z-statistics are shown in parenthesis. The number of observations differs in the different models because all data are not available for each bank, each year and each indicator. 


\section{Table A4}

\section{Contribution of market indicators and bank opacity}

Model specification : $\operatorname{Prob}\left\{\mathrm{Y}_{\mathrm{i}}=1\right\}=\Phi\left(\alpha+\alpha^{\prime} \mathrm{DOPAC}_{\mathrm{i}}+\sum_{\mathrm{j}=1}^{\mathrm{J}} \beta_{\mathrm{j}} \mathrm{C}_{\mathrm{ji}}+\sum_{\mathrm{l}=1}^{\mathrm{L}} \gamma_{1} \mathrm{M}_{\mathrm{li}}+\sum_{\mathrm{l}=1}^{\mathrm{L}} \gamma_{1}^{\prime} \mathrm{DOPAC}_{\mathrm{i}} \times \mathrm{M}_{\mathrm{li}}\right)$

DOPAC $=1$ if Deposits $/$ Total Assets $>$ Median $(67.57 \%)$

DOPAC $=0$ if Deposits $/$ Total Assets $<$ Median

\begin{tabular}{|c|c|c|c|c|}
\hline & Model 1 & Model 2 & Model 3 & Model 4 \\
\hline CONSTANT & $\begin{array}{c}-2.496^{* * * *} \\
(-6.142)\end{array}$ & $\begin{array}{c}-1.159 * * * \\
(-5.153)\end{array}$ & $\begin{array}{c}-1.318 \\
(-4.764)\end{array}$ & $\begin{array}{c}-0.704 \\
(-3.165)\end{array}$ \\
\hline DOPAC & $\begin{array}{c}-0.813 \\
(-1.361)\end{array}$ & $\begin{array}{l}-0.817^{*} \\
(-1.794)\end{array}$ & $\begin{array}{c}-0.813 * * \\
(-1.979)\end{array}$ & $\begin{array}{c}-1.138 * * * \\
(-3.227)\end{array}$ \\
\hline$\triangle I N T A P$ & $\begin{array}{c}-1.881 * * * \\
(-2.971)\end{array}$ & & & \\
\hline$\triangle \mathrm{ROE}$ & & $\begin{array}{c}-0.075 * * \\
(-2.435)\end{array}$ & $\begin{array}{c}-0.065^{* *} \\
(-2.173)\end{array}$ & $\begin{array}{c}-0.048 * * \\
(-1.991)\end{array}$ \\
\hline LNP & $\begin{array}{c}-5.323 \\
(-1.627)\end{array}$ & $\begin{array}{c}-5.567 * * * \\
(-3.11)\end{array}$ & $\begin{array}{c}-6.298 * * * \\
(-3.511)\end{array}$ & $\begin{array}{c}-6.152 * * * \\
(-4.173)\end{array}$ \\
\hline LNP $\times$ DOPAC & $\begin{array}{l}5.339 \\
(1.458)\end{array}$ & $\begin{array}{c}5.187 * * \\
(2.329)\end{array}$ & $\begin{array}{c}5.655^{* *} \\
(2.570)\end{array}$ & $\begin{array}{c}6.055^{*} * * \\
(3.011)\end{array}$ \\
\hline Mc Fadden $\mathrm{R}^{2}$ & 0.154 & 0.137 & 0.140 & 0.165 \\
\hline Total number of observations & 187 & 204 & 213 & 237 \\
\hline Number of observations of type $Y=1$ & 15 & 29 & 38 & 62 \\
\hline Risk level to reject : $\alpha^{\prime}=0$ et $\gamma_{1}^{\prime}=0 \forall 1$ & $10.60 \%$ & $0.68 \%$ & $0.26 \%$ & $0.00 \%$ \\
\hline Risk level to reject : $\gamma_{1}+\gamma_{1}^{\prime}=0 \forall 1$ & $99.19 \%$ & $78.33 \%$ & $63.34 \%$ & $94.46 \%$ \\
\hline
\end{tabular}

This table reports logit estimation results obtained with the dependent variable regressed on a constant, the accounting indicators and the market indicators previously selected. Opacity effect is taken into account with a dummy variable (DOPAC) associated with the constant and the market indicators. Models 1, 2, 3 and 4 explain downgradings occurring respectively in less than 1, 2, 3 and 4 quarters. Standard errors are adjusted using the Huber-White method. *, ** and *** indicate significance respectively at $10 \%, 5 \%$ and $1 \%$ levels. Z-statistics are shown in parenthesis. The number of observations differs in the different models because all data are not available for each bank, each year and each indicator. 
Table A5

Market reactions before and after a downgrade

for banks strongly/weakly reliant on deposits

Market reaction preceding a downgrade Banks strongly reliant on deposits

\begin{tabular}{|c|c|}
\hline & $\begin{array}{c}\text { Y (4 quarter } \\
\text { horizon) }\end{array}$ \\
\hline Constant & $\begin{array}{c}-1.716^{* * *} \\
(-6.678)\end{array}$ \\
\hline LNP & $\begin{array}{c}-1.839 \\
(-1.178)\end{array}$ \\
\hline Mc Fadden R2 & 0.013 \\
\hline Total Number of Observations & 121 \\
\hline $\begin{array}{c}\text { Number of Observations of } \\
\text { Type Y }=1\end{array}$ & 18 \\
\hline
\end{tabular}

Market reaction preceding a downgrade Banks weakly reliant on deposits

\begin{tabular}{|c|c|}
\hline & $\begin{array}{c}\text { Y (4 quarter } \\
\text { horizon) }\end{array}$ \\
\hline Constant & $\begin{array}{c}-0.730^{* * *} \\
(-3.504)\end{array}$ \\
\hline LNP & $\begin{array}{c}-5.125^{* * *} \\
(-3.738)\end{array}$ \\
\hline Mc Fadden R2 & 0.117 \\
\hline Total Number of Observations & 126 \\
\hline Number of Observations of & 45 \\
Type Y $=1$ & \\
\hline
\end{tabular}

Market reaction following a downgrade Banks strongly reliant on deposits

\begin{tabular}{|c|c|}
\hline & $\begin{array}{c}\text { Y (4 quarter } \\
\text { horizon) }\end{array}$ \\
\hline Constant & $\begin{array}{c}-1.955^{* * *} \\
(-6.191)\end{array}$ \\
\hline LNP(1) & $\begin{array}{c}-4.157^{* *} \\
(-2.047)\end{array}$ \\
\hline Mc Fadden R2 & 0.058 \\
\hline Total Number of Observations & 104 \\
\hline Number of Observations of & 12 \\
Type Y $=1$ & \\
\hline
\end{tabular}

Market reaction following a downgrade Banks weakly reliant on deposits

\begin{tabular}{|c|c|}
\hline & $\begin{array}{c}\text { Y (4 quarter } \\
\text { horizon) }\end{array}$ \\
\hline Constant & $\begin{array}{c}-1.049^{* * *} \\
(-4.249)\end{array}$ \\
\hline LNP(1) & $\begin{array}{c}-3.452^{* *} \\
(-2.220)\end{array}$ \\
\hline Mc Fadden R2 & 0.053 \\
\hline Total Number of Observations & 94 \\
\hline Number of Observations of & 26 \\
Type Y $=1$ & \\
\hline
\end{tabular}

The two sub-samples are based on the median of Deposits / Total Assets (67.57\%). Tables report logit estimation results obtained with the dependent variable regressed on a constant and LNP which is the difference between the natural logarithm of the market price and its moving average evaluated on December $31^{\text {st }}$ of the year preceding the event or LNP(1) which is evaluated on December $31^{\text {st }}$ following the event. Standard errors are adjusted using the Huber-White method. *, ** and *** indicate significance respectively at 10\%, 5\% and $1 \%$ levels. Z-statistics are shown in parenthesis. 


\section{DISTANCE TO DEFAULT}

The distance to default indicator DD that is the number of standard deviations away from the default point (ie when the value of assets $=$ the value of liabilities) is ${ }^{13}$ :

where :

$$
D D_{t}=\frac{\log \left(\frac{V_{t}}{D_{t}}\right)+\left(r_{f}-\frac{\sigma_{t}^{2}}{2}\right) T}{\sigma_{t} \sqrt{T}}
$$

$\mathrm{V}_{\mathrm{t}}$ : bank's asset value at time $\mathrm{t}$

$D_{t}$ : book value at time $t$ of the bank's debt of maturity $T$

$\mathrm{T}:$ debt maturity

$\mathrm{r}_{\mathrm{f}}$ : risk free interest rate

$\sigma_{t}:$ bank's asset value volatility

To estimate $V_{t}$ and $\sigma_{t}$ the value of equity is considered as a call option on the underlying assets with a strike price equal to the book value of the bank's debt. Hence, the market value and volatility of the bank's underlying assets can be derived from the equity's market value $(\mathrm{VE})$ and volatility $\left(\sigma_{\mathrm{E}}\right)$ by solving :

$$
\left\{\begin{array}{l}
V_{t}=\frac{V E_{t}+D_{t} e^{-r_{f} T} N(d 2)}{N(d 1)} \\
\sigma_{t}=\frac{\frac{V E_{t}}{V_{t}} \sigma_{E, t}}{N(d 1)}
\end{array}\right.
$$

where :

$$
\begin{aligned}
& d 1=\frac{\log \left(\frac{V_{t}}{D_{t}}\right)+\left(r_{f}+\frac{\sigma_{t}^{2}}{2}\right) T}{\sigma_{t} \sqrt{T}} \\
& d 2=d 1-\sigma_{t} \sqrt{T}
\end{aligned}
$$

Daily market values of the bank's equity (VE) are taken from Datastream. The volatility of the bank's equity $\left(\sigma_{\mathrm{E}}\right)$ is calculated on the quarter preceding the end of the calendar year (ie 65 trading days) as the standard deviation of daily equity returns multiplied by $\sqrt{365}$.

The expiry date of the option (T) is in this case equal to the maturity of the debt. A common assumption is to set it to 1 (one year) ${ }^{14}$. We took the 12 months interbank rates from Datastream to compute risk free rates except for Greece where we used the 6 months interbank rate. Data on debt liabilities were taken from Bankscope. The total amount of liabilities is calculated as the total amount of deposits, money market funding, bonds, subordinated debt and hybrid capital.

\footnotetext{
${ }^{13}$ For details see Crosbie (1999), Gropp, Vesala and Vulpes (2005).

${ }^{14}$ See Crosbie (1999), Gropp, Vesala and Vulpes (2005).
} 


\section{REFERENCES}

BANK FOR INTERNATIONAL SETTLEMENTS, (2003), "Overview of the New Basel Capital Accord", Consultative Document April

BERGER A. N., DAVIES S. M., FLANNERY M. J., (2000), "Comparing Market and Supervisory Assessments of Bank Performance : Who Knows What When ?", Journal of Money, Credit and Banking, pp 641-667

BILLETT M.T., GARFINKEL J.A., O'NEAL E.S., (1998), "The Cost of Market versus Regulatory Discipline in Banking", Journal of Financial Economics 48, pp 333-358

BLACK F., SCHOLES M., (1973), "The Pricing of Options and Corporate Liabilities", Journal of Political Economy, pp 637-654

CROSBIE P. J., (1999), "Modeling Default Risk", KMV Corporation

CROUZILlE C., LEPETIT L., TARAZI A. (2004),"Bank Stock Volatility, News and Asymmetric Information in Banking : an Empirical Investigation", Journal of Multinational Financial Management, vol 14, pp 443-461

CURRY T. J., ELMER P. J., FISSEL G. S., (2002), "Regulator Use of Market Data to Improve the Identification of Bank Financial Health", FDIC Working Paper

CURRY T. J., ELMER P. J., FISSEL G. S., (2003), "Using Market Information to Help Identify Distressed Institutions : A Regulatory Perspective", FDIC Banking Review, vol. 15, $\mathrm{n}^{\circ} 3$

DIAMOND D. W., (1984), "Financial Intermediation and Delegated Monitoring", Review of Economic Studies 54, pp 393-414

DIAMOND D. W., DYBVIG P. H., (1983), "Bank runs, deposit insurance and liquidity", Journal of Political Economy, vol. 91, pp 401-419

ELMER P. J., FISSEL G., (2001), "Forecasting Bank Failure From Momentum Patterns in Stock Returns", Federal Deposit Insurance Corp. Working Paper

ESTRELlA A., PARK S., PERISTANI S., (2000), "Capital Ratios as Predictors of bank Failure", Economic Policy Review,July

EVANOFF D. D., WALL L. D., (2000), "Subordinated Debt and Bank Capital Reform", Federal Reserve Bank of Chicago, Working Papers

EVANOFF D. D., WALL L. D., (2001), "Sub-debt yield spreads as bank risk measures", Federal Reserve Bank of Chicago, Working Papers 
EVANOFF D. D., WALL L. D., (2002), "Measures of the Riskiness of Banking Organisations : Subordinated Debt Yields, Risk-Based Capital, and Examination Ratings", Journal of Banking and Finance

EVANOFF D. D., WALL L. D., (2002), "Subordinated Debt and Prompt Corrective Regulatory Action", Federal Reserve Bank of Atlanta, Working Paper Series , August

FELDMAN R., LEVONIAN M., (2001), "Market Data and Bank Supervision: The Transition to Practical Use", Federal Reserve Bank of Minneapolis The Region, pp 11-13, 46-54

FLANNERY M. J., (1998), "Using Market Information in Prudential Bank Supervision: A Review of the U.S. Empirical Evidence", Journal of Money Credit and Banking, vol. 30(3) pp 273-30

FLANNERY M. J., (2001), "The Faces of Market Discipline", Journal of Financial Services Research October/December, pp 107-119

GOYEAU D., SAUVIAT A., TARAZI A. (1998), "Taille, rentabilité et risque bancaire, évaluation empirique et perspectives pour la réglementation prudentielle", Revue d'Economie Politique vol. 108, n³, pp 339-361

GOYEAU D., SAUVIAT A., TARAZI A., (2001), "Marché financier et évaluation du risque bancaire. Les agences de notation contribuent-elles à améliorer la discipline de marché ?", Revue Economique 52, mars, pp 265-283

GOYEAU D., TARAZI A., (1992), "Evaluation du risque de défaillance bancaire en Europe", Revue d'Economie Politique, 102 pp 250-280

GROPP R., VESALA J., VULPES G., (2005), "Equity and Bond Market Signals as Leading Indicators of Bank Fragility", Journal of Money Credit and Banking, forthcoming.

GUNTHER J. W., LEVONIAN M. E., MOORE R. R., (2001), "Can the Stock Market tell Bank Supervisors Anything They Don't Already Know ?", Federal Reserve Bank of Dallas

JAGTIANI J., KAUFMAN G., LEMIEUX C., (1999), "Do Markets Discipline Banks and Bank Holding Companies? Evidence from Debt Pricing", Federal Reserve Bank of Chicago

JAGTIANI J., LEMIEUX C., (2001), "Market Discipline Prior to Bank Failure", Journal of Economics and Business vol. 53, pp 313-324

KRAINER J., LOPEZ J. A., (2004), "Using Securities Market Information for Bank Supervisory Monitoring", Federal Reserve Bank of San Francisco Working paper

KMV Corporation (2003) : “Modelling Risk”, San Francisco : KMV Corporation

LELAND H. E., PYLE D. H., (1977), "Informational Asymmetries, Financial Structure, and Financial Intermediation", The Journal of Finance vol. 32, pp 371-387

LOGAN A., (2000), "G10 Seminar on Systems for assessing Banking System Risk", Financial Stability Review, June 
MERTON R. C., (1977), "On the Pricing of Contingent Claims and the Modigliani-Miller Theorem", Journal of Financial Economics 5, pp 241-249

RONN E. I., VERMA A. K., (1986), "Pricing Risk-Adjusted Deposit Insurance : An OptionBased Model", Journal of Finance, pp 871-895

SAHAJWALA R., VAN DEN BERGH P., (2000), "Supervisory Risk Assessment and Early Warning Systems", Basel Committee on Banking Supervision working papers no. 4

SIRONI A., (2003), "Testing for Market Discipline in the European Banking Industry : Evidence from Subordinated Debt Issues", Jounal of Money, Credit and Banking, vol. 35, pp 443-472

WHALEN G., THOMSON J. B., (1988), "Using Financial Data to Identify Changes in Bank Condition", Federal Reserve Bank of Cleveland Economic Review, pp 18-26 